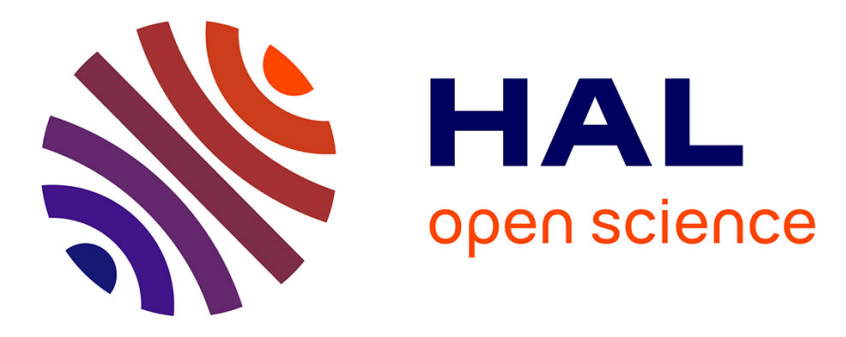

\title{
MAGLAB: A computing platform connecting geophysical signatures to melting processes in Earth's mantle
}

Malcolm Massuyeau, Emmanuel Gardés, Grégory Rogerie, Sonja Aulbach, Sebastian Tappe, Emmanuel Le Trong, David Sifré, Fabrice Gaillard

\section{To cite this version:}

Malcolm Massuyeau, Emmanuel Gardés, Grégory Rogerie, Sonja Aulbach, Sebastian Tappe, et al.. MAGLAB: A computing platform connecting geophysical signatures to melting processes in Earth's mantle. Physics of the Earth and Planetary Interiors, 2020, pp.106638. 10.1016/j.pepi.2020.106638 . insu-03092861

\section{HAL Id: insu-03092861 https://hal-insu.archives-ouvertes.fr/insu-03092861}

Submitted on 3 Jan 2021

HAL is a multi-disciplinary open access archive for the deposit and dissemination of scientific research documents, whether they are published or not. The documents may come from teaching and research institutions in France or abroad, or from public or private research centers.
L'archive ouverte pluridisciplinaire HAL, est destinée au dépôt et à la diffusion de documents scientifiques de niveau recherche, publiés ou non, émanant des établissements d'enseignement et de recherche français ou étrangers, des laboratoires publics ou privés. 


\section{Journal Pre-proof}

PHYSICS

OF THE EARTH

MAGLAB: A computing platform connecting geophysical signatures to melting processes in Earth's mantle

Malcolm Massuyeau, Emmanuel Gardés, Grégory Rogerie, Sonja Aulbach, Sebastian Tappe, Emmanuel Le Trong, David Sifré, Fabrice Gaillard
AND PLANETARY

INTERIORS

PII: $\quad$ S0031-9201(20)30398-8

DOI: $\quad$ https://doi.org/10.1016/j.pepi.2020.106638

Reference: $\quad$ PEPI 106638

To appear in: $\quad$ Physics of the Earth and Planetary Interiors

Received date: $\quad 7$ July 2020

Revised date: $\quad 30$ October 2020

Accepted date: $\quad 24$ December 2020

Please cite this article as: M. Massuyeau, E. Gardés, G. Rogerie, et al., MAGLAB: A computing platform connecting geophysical signatures to melting processes in Earth's mantle, Physics of the Earth and Planetary Interiors (2020), https://doi.org/10.1016/ j.pepi.2020.106638

This is a PDF file of an article that has undergone enhancements after acceptance, such as the addition of a cover page and metadata, and formatting for readability, but it is not yet the definitive version of record. This version will undergo additional copyediting, typesetting and review before it is published in its final form, but we are providing this version to give early visibility of the article. Please note that, during the production process, errors may be discovered which could affect the content, and all legal disclaimers that apply to the journal pertain.

(C) 2020 Published by Elsevier. 


\section{MAGLAB: a computing platform connecting geophysical signatures to melting processes in Earth's mantle}

Malcolm Massuyeau ${ }^{1,2, \dagger}$, Emmanuel Gardés ${ }^{3}$, Grégory Rogerie ${ }^{1}$, Sonja Aulbach ${ }^{4}$, Sebastian Tappe $^{2}$, Emmanuel Le Trong ${ }^{1}$, David Sifré ${ }^{1,5}, \&$ Fabrice Gaillard ${ }^{1}$

${ }^{1}$ Institut des Sciences de la Terre d'Orléans (ISTO), Université d'Orléans-CNRS-BRGM, 1A rue de la Férollerie, 45071 Orléans cedex 2, France.

${ }^{2}$ Deep \& Early Earth Processes (DEEP) Research Group, Department of Geology, University of Johannesburg, P.O. Box 524, Auckland Park 2006, South Africa.

${ }^{3}$ Centre de Recherche sur les Ions, les Matériaux et la Photonique (CIMAP), Normandie Université, ENSICAEN, UNICAEN, CEA, CNRS, Boulevard Henri Becquerel, BP 5133, F14070 Caen cedex 5, France.

${ }^{4}$ Institut für Geowissenschaften, Goethe-Universität, Facheinl eit Mineralogie, Abt. Petrologie und Geochemie, Altenhöferallee 1, D-60438 Frankfurt am ${ }^{\wedge}{ }^{\wedge} u_{1}$, Jermany.

${ }^{5}$ European Synchrotron Radiation Facility (ESRF), 71 a en - des Martyrs CS 40220, 38043 Grenoble Cedex 9, France.

Corresponding author: Malcolm Massuyeau (nalcuim.massuyeau@wwu.de)

†present address: Institute for Mineralogs U iiversity of Münster, Münster, Germany.

\section{Keywords}

Petrological-geophysical modelin; Melt fraction-composition; Upper mantle; $\mathrm{CO}_{2}-\mathrm{H}_{2} \mathrm{O}$ volatiles; Intraplate magmas; I ho ${ }_{1}$ here-asthenosphere boundary 


\begin{abstract}
Decompression melting of the upper mantle produces magmas and volcanism at the Earth's surface. Experimental petrology demonstrates that the presence of $\mathrm{CO}_{2}$ and $\mathrm{H}_{2} \mathrm{O}$ enhances peridotite melting anywhere within the upper mantle down to approximately 200$300 \mathrm{~km}$ depth. The presence of mantle melts with compositions ranging from carbonate-rich to silicate-rich unavoidably affects the geophysical signals retrieved from Earth's mantle. Geochemical investigations of erupted intraplate magmas along with geophysical surveys allow for constraining the nature and volume of primary melts, and a sound formalism is required to integrate these diverse datasets into a realistic model for the upper mantle including melting processes. Here, we introduce MAGLAB, a model developed to calculate the composition and volume fraction of melts in the upper mantle, together with the corresponding electrical conductivity of partially molten mantle peridotites at realistic pressure-temperature conditions and volatile contents. We use MAGLAB to show how the compositions of intraplate magmas relate to variations in lith, nhere thickness. Progressive partial melting of a homogeneous peridotitic mantle source $r$ an in theory create the diversity of compositions observed among the spectrum of intraplate ragma types, with kimberlite melts beneath thick continental shields, alkaline magmas su h as melilitite, nephelinite and basanite beneath thinner continents and relatively old plus thick oceanic lithospheres, and 'regular' basalts beneath the youngest and thinnest $\pi \cdot \mathrm{mlic}_{\mathrm{c}}$ lithospheres as well as beneath significantly thinned continental lithospheres. $\mathrm{N}_{\mathrm{L}^{1}}{ }^{\prime} \mathrm{r}^{\prime} \mathrm{AB}$ calculations support recent experimental findings about the role of $\mathrm{H}_{2} \mathrm{O}$ in he upper mantle on producing primary kimberlitic melts in addition to $\mathrm{CO}_{2}$. We $d$ in onstrate the robustness of MAGLAB calculations by reproducing the compositions of u upted melts as well as associated mantle electrical conductivities beneath the Soc sty hotspot in the Pacific Ocean. A comparison of our simulations with magnetotelluric sur ys at various oceanic settings shows that the heterogeneities in electrical conductiv ${ }^{\text {tv }}$ of Larth's upper mantle are related to variations in volatile content via the presence ot small (generally $<<1 \quad w t \%$ ) and heterogeneously distributed fractions of $\mathrm{CO}_{2}-\mathrm{H}_{2} \mathrm{O}-\mathrm{b}_{\mathrm{a}} \mathrm{ar}_{i}$, melts.
\end{abstract}




\section{Introduction}

The flux of heat from Earth's interior generates upwelling limbs of convective cells, such as passive upwelling beneath mid-ocean ridges, or plumes occurring beneath hotspots (Ballmer et al., 2011; French and Romanowicz, 2015). Within these convective cells, the upper mantle is expected to produce partial melts of variable fractions and compositions. Mantle melting is enhanced by the presence of the volatiles $\mathrm{CO}_{2}$ and $\mathrm{H}_{2} \mathrm{O}$. The upper mantle volatile contents average around 140 wt ppm $\mathrm{CO}_{2}$ and 240 wt ppm $\mathrm{H}_{2} \mathrm{O}$ (Le Voyer et al., 2017), but are highly variable with concentrations ranging from some wt ppm to many hundreds of wt ppm as reported in geochemical surveys (Marty, 2012; Le Voyer et al., 2017; Hirschmann, 2018; Hauri et al. 2019; Shimizu et al., 2019). Experimental petrology provides numerous constraints on partial melting properties of peridotite in presence of volatiles within the pressure-temperature-composition conditions prevailing in Earth's upper mantle. These studies emphasize the large effect of $\mathrm{CO}_{2}$ and $\mathrm{H}_{2} \mathrm{O}$ on mantle 1 alting relations, where these volatiles drastically lower the solidus of peridotite to $\left\langle 100 \mathrm{C}^{ } \mathrm{C}\right.$, Wallace and Green, 1988; Dasgupta and Hirschmann, 2006; Hammouda and Keshav, ?, ,J; Gardés et al., 2020). $\mathrm{CO}_{2^{-}}$ $\mathrm{H}_{2} \mathrm{O}$-assisted melting is thus predicted for most of the ner mantle as long as the oxidized form of carbon (i.e. carbonate) is stable. The depth at which the transition from oxidized to reduced carbon occurs is debated, with options rangin ; fre $\mathrm{n} \sim 150 \mathrm{~km}$ (Stagno et al., 2013) to $\sim 250 \mathrm{~km}$ (Rohrbach and Schmidt, 2011). More recen ,udies (Gaillard et al., 2015; Eguchi and Dasgupta, 2018; Moussallam et al., 2010; argue that the asthenosphere may be much more oxidized than previously deduced from $d \epsilon$ ' $2 t f d$ peridotite samples of the deep cratonic lithosphere (Stagno et al., 2013). Such du cratonic mantle lithosphere may also have experienced various stages of meta om cism and oxidation over time by infiltrating carbonate-bearing hydrous silicate melts $\mathrm{c}$ - by the incorporation of subducted carbonatebearing crustal material (Yaxley et al., 2017). The presence and role of volatile-bearing melts in both oceanic and continental up $\iota^{-1}$ hantle have been emphasized based on petrological investigations and geophysical ous rrations. Geochemical studies have deduced their existence by observing characteri tic netasomatic overprints of rocks as well as the presence of fluid/melt-derived inclusions in rantle minerals (Bodinier et al., 1990; Grégoire et al., 2003; Klein-BenDavid et al., 20u?; O’Reilly and Griffin, 2010; Weiss et al., 2011; Tumiati et al., 2013; Pilet et al., 20 ५). Seismic and magnetotelluric surveys have reported geophysical anomalies in the upper mat le, such as reduced seismic shear-wave velocities in the LowVelocity Zone (LVZ) lo $\_$d between $\sim 50$ and 150-200 km depth, and high electrical conductivities at similar (epths, both enhanced by the presence of low volumes of melt potentially containing appreciable amounts of $\mathrm{CO}_{2}$ and $\mathrm{H}_{2} \mathrm{O}$ (Eggler, 1976; Gaillard et al., 2008; Kawakatsu et al., 2009; Fischer et al., 2010; Hirschmann, 2010; Ni et al., 2011; Schmerr, 2012; Naif et al., 2013; Sifré et al., 2014; Chantel et al., 2016; Holtzmann, 2016; Aulbach et al., 2017; Katsura et al., 2017; Kawakatsu and Utada, 2017; Tharimena et al., 2017a,b; Soltanmohammadi et al., 2018; Selway and O'Donnell, 2019; Selway et al., 2019; Rychert et al., 2020; Gardés et al., 2020). Interestingly, reworking, rejuvenation and ultimate loss of deep cratonic lithosphere sections (e.g., North Atlantic craton, North China craton, Tanzania craton) have been suggested to be an expression of intense metasomatic weakening due to repeated passage of volatile-bearing melts (Tappe et al., 2007; Foley, 2008; Aulbach et al., 2017; Liu et al., 2019).

A wide range of magmatic liquids is stable in the upper mantle, ranging from carbonatites with low silica content at high pressures (i.e., great depths), to basanites-basalts with relatively high silica content at low pressures (Gudfinnsson and Presnall, 2005; Dasgupta et al., 2013; Massuyeau et al., 2015). Indeed, near-solidus melts of peridotite in the 
presence of $\mathrm{CO}_{2}$ and $\mathrm{H}_{2} \mathrm{O}$ are typically $\mathrm{SiO}_{2}$-poor (Foley et al., 2009), and decreasing pressure and increasing temperature increases the $\mathrm{SiO}_{2}$ content of peridotite-derived melts (Gudfinnsson and Presnall, 2005; Dasgupta et al., 2007, 2013; Massuyeau et al., 2015). The compositional diversity of mantle-derived melts is evidenced by the variability of intraplate magma compositions observed at the Earth's surface (Fig. 1). Some petrogenetic links have been established between the compositional diversity of mantle-derived magmas from oceanic (e.g., ocean island basalts (OIB)) to continental (e.g., kimberlite) intraplate settings and differences in the pressure of melt extraction from a compositionally similar upwelling mantle source (le Roex, 1986; Ringwood et al., 1992; Gudfinnsson and Presnall, 2005; Tappe et al., 2013 , 2018). On the other hand, geochemical studies have defined empirical relationships between the composition of basalts and the depth of melt extraction, i.e. the mean extent of melting, which is strongly controlled by lithospheric thickness (Ellam, 1992; Haase, 1996; Prytulak and Elliott, 2007; Humphreys and Niu, 2009; Dasgupta et al., 2010; Niu et al., 2011; Davies et al., 2015; Niu and Green, 2018; Guo et c ${ }^{1}$. 2020). Therefore, first-order variability in primitive basaltic melt compositions appears to rela: to lithospheric thickness. However, a unifying model relating melt compositions in a vers: tectonic settings, such as oceanic and continental intraplate magmatism, to lithosphe $\mathbb{1}$ thickness is still lacking. Such a model requires describing chemical and physical prope the if mantle melts by interpolating and extrapolating experimental data and comparing the. with petrological and geophysical datasets for the terrestrial upper mantle. However, moc els calculating the compositions and fractions of melts equilibrated with peridotite in the presence of $\mathrm{CO}_{2} \pm \mathrm{H}_{2} \mathrm{O}$ are sparse (Dasgupta et al., 2007, 2013; Hirschmann, 20'v, Ghosh et al., 2014; Ghiorso and Gualda, 2015; Massuyeau et al., 2015). Importantly 1. inf of the existing models covers the whole compositional spectrum of mantle-deriver. me.ts equilibrated with peridotite within a large pressure-temperature $(P-T)$ window, frc $\eta r$ arbonatitic to basaltic compositions, or allows for the calculation of both (i) composition and : "action of melt and (ii) corresponding geophysical response of partially molten mantle per. ${ }^{-1}$ otite.

Here, we report on a $n \cdot v$ wodeling platform, called MAGLAB (http://calculisto.cnrs-orleans.fr/apps/maglab/, which allows within a single framework to calculate (i) the compositions and fractions oi melts equilibrated in the upper mantle as a function of its volatile content $\left(\mathrm{CO}_{2}\right.$ and $\left.\mathrm{H}^{\prime} \mathrm{C}^{\prime}\right)$ and (ii) corresponding electrical conductivities of partially molten peridotite under urner nantle conditions. MAGLAB covers most of the pressuretemperature-volatile cons in $n$ of the terrestrial upper mantle and reproduces the full spectrum of intrapla: maride-derived melts within their domain of stability, i.e. from carbonatitic and kimberm ic through to basanitic and basaltic compositions. This approach allows for simulating electrical conductivity profiles within a constrained petrological framework under relevant mantle conditions. The first part of this contribution presents the structure, formulations, and applicability of MAGLAB (Sections 2 and 3). Melt compositions, melt fractions and electrical conductivities of partially molten peridotite as a function of geodynamic setting are highlighted in Section 4. Based on our results, we demonstrate in Section 5, by using melt $\mathrm{SiO}_{2}$ content as a first-order discriminant, that lithosphere thickness controls primary melt compositions. A diversity of intraplate magma compositions can be produced as a function of the depth of the lithosphere-asthenosphere boundary (LAB) even if only a single volume of upwelling mantle material is involved. The validity of MAGLAB model outputs for both melt fractions and compositions along with geophysical responses is then illustrated for a well-constrained intraplate setting, the Society hotspot in the Pacific Ocean. Section 5 furthermore shows the excellent match between the range of electrical conductivity simulated by MAGLAB for the Earth's upper mantle with realistic heterogeneities in $\mathrm{CO}_{2}-\mathrm{H}_{2} \mathrm{O}$ content and the heterogeneities in electrical conductivity of the oceanic upper mantle reported from magnetotelluric surveys. 


\section{The MAGLAB model}

MAGLAB aims at calculating the composition and the fraction of melt in chemical equilibrium with mantle peridotite at a given pressure, temperature and bulk rock $\mathrm{CO}_{2}$ and $\mathrm{H}_{2} \mathrm{O}$ content. As detailed in following sections, MAGLAB calculates melt compositions in the system $\mathrm{SiO}_{2}-\mathrm{TiO}_{2}-\mathrm{Al}_{2} \mathrm{O}_{3}-\mathrm{FeO}-\mathrm{CaO}-\mathrm{MgO}-\mathrm{Na}_{2} \mathrm{O}-\mathrm{K}_{2} \mathrm{O}-\mathrm{H}_{2} \mathrm{O}-\mathrm{CO}_{2}$, based on the silica activity of the melt (i.e., how ideal is the mixing between silica and other melt components). Silica activity is calculated at given $P-T$ conditions and olivine-orthopyroxene compositions, and three compositional end-members (silicate, carbonate, $\mathrm{H}_{2} \mathrm{O}$ ) are mixed in order to determine the melt composition that reproduces this activity best. At a given bulk rock $\mathrm{CO}_{2}$ and $\mathrm{H}_{2} \mathrm{O}$ content, the melt fraction is obtained by mass balance using the $\mathrm{CO}_{2}$ and $\mathrm{H}_{2} \mathrm{O}$ concentrations of the melt and volatile partitioning between melt and peridotite. Once melt composition and melt fraction have been determined, MAGLAB calculates the electrical conductivity of corresponding partially molten mantle peridotite.

\subsection{Calculation of melt composition and fraction at $u, p e \cdot$ mantle conditions}

The MAGLAB model first calculates melt - w. npusition and melt fraction at given pressure, temperature and bulk rock $\mathrm{CO}_{2}$ and $\mathrm{H}_{2} \mathrm{O}$ n' ent. The compositions of $\mathrm{CO}_{2}-\mathrm{H}_{2} \mathrm{O}$ bearing melts in pressure-temperature-bulk rock cc.npostion space are calculated according to a thermodynamic model modified after Ma st ye au et al. (2015). The melt-mantle rock equilibrium is simplified according to the reacion

$\mathrm{Mg}_{2} \mathrm{SiO}_{4}+\mathrm{SiO}_{2}($ melt $)=\mathrm{Mg}_{2} \mathrm{Si}_{2} \mathrm{O}_{\epsilon}(1)$

where $\mathrm{Mg}_{2} \mathrm{SiO}_{4}$ is the forsterite c mp ant of olivine, $\mathrm{Mg}_{2} \mathrm{Si}_{2} \mathrm{O}_{6}$ is the enstatite component of orthopyroxene, and $\mathrm{SiO}_{2}$ (melt) it the silica component of melt. Equilibrium implies

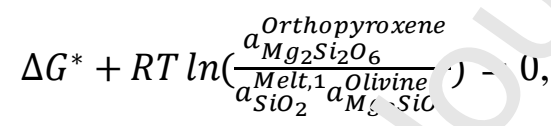

$$
\begin{aligned}
& \text { or } a_{\mathrm{SiO}_{2}}^{\mathrm{Melt}, 1}=\exp \left(\frac{\Delta G^{*}}{R T}\right)\left(\frac{a_{\mathrm{Mg}_{2} \mathrm{Si}_{2} \mathrm{O}_{6}}^{\text {Orthoxe }}}{a_{\mathrm{Mg}_{2} \mathrm{SiO}_{4}}^{\text {Olivine }}}\right),
\end{aligned}
$$

where $\Delta G^{*}$ is the standard state Gibbs free energy of reaction (1), $a_{i}^{j}$ is the activity of component $i$ in phase $j, R$ is the gas constant and $T$ the absolute temperature. At given $P$ and $T, a_{\mathrm{SiO}_{2}}^{\mathrm{Melt}, 1}$ is obtained by calculating $\Delta G^{*}$ according to the data of Holland and Powell (2011) (Section 1 of the Supplementary Information). Mineral activities are given by $a_{\mathrm{Mg}_{2} \mathrm{SiO}_{4}}^{\mathrm{Olivine}_{4}}=$ $X_{M g}^{M 1, \text { olivine }} X_{M g}^{M 2, \text { olivine }}$ and $a_{M g_{2} S_{2} \mathrm{O}_{6}}^{\text {Orthopyroxe }}=X_{M g}^{M 1, \text { Orthopyroxene }} X_{M g}^{M 2, \text { orthopyroxene }}$, where

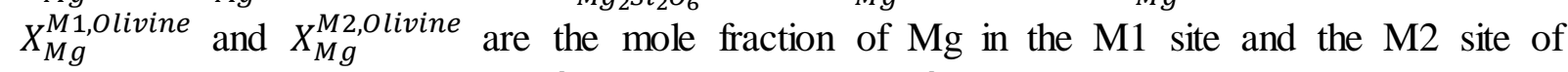
olivine, respectively, and $X_{M g}^{M 1, \text { Orthopyroxene }}$ and $X_{M g}^{M 2, \text { orthopyroxene }}$ are the mole fraction of $\mathrm{Mg}$ in the M1 site and the M2 site of orthopyroxene, respectively (see more details about calculations of mineral activities in Massuyeau et al. (2015)). $\mathrm{SiO}_{2}$ mixing in melt is not 
considered ideal. Massuyeau et al. (2015) found that the activity coefficient of $\mathrm{SiO}_{2}$ in the melt, $\gamma_{\mathrm{SiO}_{2}}^{\mathrm{Melt}}$, which describes the deviation from ideal behavior of the mixing between $\mathrm{SiO}_{2}$ and other components (DeCapitani and Kirschen, 1998), is well modeled in the $\mathrm{SiO}_{2}-\mathrm{TiO}_{2}$ $\mathrm{Al}_{2} \mathrm{O}_{3}-\mathrm{FeO}-\mathrm{CaO}-\mathrm{MgO}-\mathrm{Na}_{2} \mathrm{O}-\mathrm{K}_{2} \mathrm{O}-\mathrm{H}_{2} \mathrm{O}-\mathrm{CO}_{2}$ space as:

$$
\begin{aligned}
& R T \ln \left(\gamma_{\mathrm{SiO}_{2}}^{\mathrm{Melt}}\right)=W_{\mathrm{SiO}_{2}-\mathrm{CO}_{2}}^{\mathrm{a}}\left(2 \mathrm{X}_{\mathrm{SiO}_{2}}^{\mathrm{Melt}} X_{\mathrm{CO}_{2}}^{\mathrm{Melt}}-2\left(X_{\mathrm{SiO}_{2}}^{\mathrm{Melt}}\right)^{2} \mathrm{X}_{\mathrm{CO}_{2}}^{\mathrm{Melt}}\right)+
\end{aligned}
$$

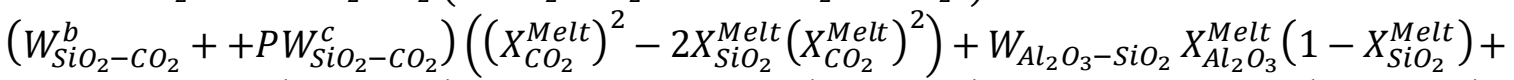

$$
\begin{aligned}
& W_{\mathrm{CaO}-\mathrm{SiO}_{2}} \mathrm{XaO}_{\mathrm{CaOl}}^{\mathrm{Melt}}\left(1-\mathrm{X}_{\mathrm{SiO}_{2}}^{\mathrm{Melt}_{2}}\right)+W_{\mathrm{Na}_{2} \mathrm{O}-\mathrm{SiO}_{2}} X_{\mathrm{Na}_{2} \mathrm{O}}^{\mathrm{Melt}}\left(1-X_{\mathrm{SiO}_{2}}^{\mathrm{Melt}}\right)+W_{\mathrm{K}_{2} \mathrm{O}-\mathrm{SiO}_{2}} X_{\mathrm{K}_{2} \mathrm{O}}^{\mathrm{Melt}}\left(1-\mathrm{X}_{\mathrm{SiO}_{2}}^{\mathrm{Melt}}\right)-
\end{aligned}
$$

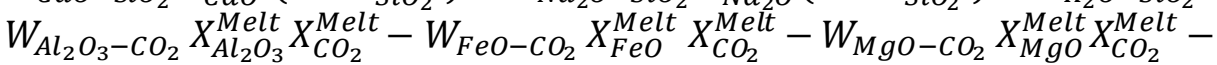

$$
\begin{aligned}
& W_{\mathrm{Na}_{2} \mathrm{O}-\mathrm{CO}_{2}} \mathrm{XNa}_{\mathrm{Na}_{2} \mathrm{O}}^{\mathrm{Melt}} \mathrm{CO}_{2}^{\mathrm{Melt}}-W_{\mathrm{K}_{2} \mathrm{O}-\mathrm{CO}_{2}} X_{\mathrm{K}_{2} \mathrm{O}}^{\mathrm{Melt}} X_{\mathrm{CO}_{2}}^{\mathrm{Melt}}-W_{\mathrm{H}_{2} \mathrm{O}-\mathrm{CO}_{2}} \mathrm{X}_{\mathrm{H}_{2} \mathrm{O}}^{\mathrm{Melt}} \mathrm{XCO}_{\mathrm{CO}_{2}}^{\mathrm{Melt}}-
\end{aligned}
$$

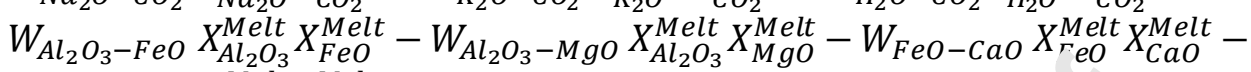

$$
\begin{aligned}
& W_{\mathrm{CaO}-\mathrm{Na}_{2} \mathrm{O}} \mathrm{XCaO}_{\mathrm{Melt}}^{\mathrm{Melt}} \mathrm{Na}_{2} \mathrm{O} \text {, (3) }
\end{aligned}
$$

where the pressure $P$ is expressed in bar, $X_{i}^{\text {Melt }}$ is the mo ar h action of oxide $i$ in melt and the $W_{i-j}$ are the Margules parameters, i.e. the interaction $\mathrm{f}_{\mathrm{f}}$ ranuters between two melt oxides $i$ and $j$. Noteworthy, Eq. (3) is modified from Massu ea et al. (2015) by the addition of a pressure-dependent Margules parameter $W_{\mathrm{SiO}_{2}-\mathrm{CO}_{2}}^{\mathrm{C}} \mathrm{l}$ - .he interaction $\mathrm{SiO}_{2}-\mathrm{CO}_{2}$. This term was added since it allows for a better reprod $\cdots$ tion of the progressive transition between carbonate-rich to silicate-rich melts with pressure se details in Section 3; Stagno and Frost, 2010; Dasgupta et al., 2013; Massuyeau et $7 l$. , 2015). The activity of $\mathrm{SiO}_{2}$ in the melt can then be calculated from Eq. (3) accordins to

$a_{\mathrm{SiO}_{2}}^{\mathrm{Melt}, 2}=X_{\mathrm{SiO}_{2}}^{\mathrm{Melt}} \gamma_{\mathrm{SiO}_{2}}^{\mathrm{Melt}}$

The Margules parameters in En ( 2 , are optimized so that $a_{\mathrm{SiO}_{2}}^{\mathrm{Melt,2}}$ calculated from experimental melt compositions following Li: (4) best reproduces $a_{S i O_{2}}^{M e l t}$ calculated from experimental $P$ and $T$ following Eq. ( 2 ) $T$, ibles S1-S2; more details about the calculations and the optimization procedure c. $\mathrm{n}$ b found in Massuyeau et al. (2015)). The optimization was done over an extended expe i mental database covering a large range of pressure, temperature and composition conditions re'evant to the upper mantle. It regroups 678 melting experiments at pressures and temperatures ranging from 1 to $14 \mathrm{GPa}$ and 1020 to $1950^{\circ} \mathrm{C}$, and bulk rock $\mathrm{CO}_{2}$ and $\mathrm{H}_{2} \mathrm{O}$ contents from 0 to $10-20 \mathrm{wt} \%$ (Fig. 2A; see also Table S3). This corresponds to 187 more entries than in Massuyeau et al. (2015). MAGLAB reproduces experimental data to within $\sim 15 \%$ based on the average relative deviation of MAGLAB calculations for the whole database (Fig. 3).

Once the Margules parameters are optimized over the experimental database, MAGLAB can be used to calculate mantle-derived melt compositions at any $P$ and $T$. First, the activity of $\mathrm{SiO}_{2}$ in the melt $a_{\mathrm{SiO}_{2}}^{\mathrm{Melt}, 1}$ is calculated from Eq. (2) at $P$ and $T$ of interest, assuming a pressure-dependent activity ratio $\frac{a_{\mathrm{Mg}_{2} \mathrm{Si}_{2} \mathrm{O}_{6}}^{\text {Orthone }}}{a_{\mathrm{Mg}_{2} \mathrm{SiO}_{4}}}$ for the upper mantle estimated from experimental data (Fig. S1; see details in Section 2 of the Supplementary Information). Then, the method consists in finding the composition for which the $\mathrm{SiO}_{2}$ activity $a_{\mathrm{SiO}_{2}}^{\mathrm{Melt}, 2}$ calculated from Eq. (4) matches the $\mathrm{SiO}_{2}$ activity $a_{S i O}^{M e l t, 1}$ calculated from Eq. (2) (see Fig. S2). However, 
instead of searching for a solution in the whole $\mathrm{SiO}_{2}-\mathrm{TiO}_{2}-\mathrm{Al}_{2} \mathrm{O}_{3}-\mathrm{FeO}-\mathrm{CaO}-\mathrm{MgO}-\mathrm{Na}_{2} \mathrm{O}-\mathrm{K}_{2} \mathrm{O}-$ $\mathrm{H}_{2} \mathrm{O}-\mathrm{CO}_{2}$ compositional space, we designed MAGLAB to work in the space of three endmembers: silicate $(S)$, carbonate $(C)$ and $\mathrm{H}_{2} \mathrm{O}(H)$. The melt composition is thus calculated as a linear combination of the three end-members, i.e. $\alpha S+\beta C+\varepsilon H$, where the coefficients $\alpha, \beta$ and $\varepsilon$ are optimized for minimizing the difference between $a_{\mathrm{SiO}_{2}}^{\mathrm{Melt}, 1}$ and $a_{\mathrm{SiO}_{2}}^{\mathrm{Melt}, 2}$ (with $\alpha, \beta$ and $\varepsilon$ being all positive and such that $\alpha+\beta+\varepsilon=1$ ). The use of these three end-members reduces the degrees of freedom but their compositions were defined in a way that their combination covers most of the compositional range of both experimental and natural melts (Figs 2B-S3). This procedure allows for reproducing a wide range of natural volatile-bearing melts produced in equilibrium with peridotite, from carbonatites to kimberlites to basanites and basalts. Strongly alkaline magmas and intrusive carbonatites, as well as some kimberlites and basalts, may require additional differentiation processes or the involvement of other lithologies such as eclogite, pyroxenite or hornblendite, which are not treated by the present model (Hirschmann et al., 2003; Sobolev et al., 2007; Pilet e. al., 2008; Doucelance et al., 2010; Baudouin et al., 2016; Tappe et al., 2017; Weidendorf . ot cil., 2017; Lu et al., 2020). Note that the compositions of the silicate and carbonate me. er 1 -members are not constant but vary as a function of pressure (Fig. S4 and Table '4). Moreover, the pure $\mathrm{H}_{2} \mathrm{O}$ endmember allows water content to vary independently fror $1 \mathrm{~L} \mathcal{\Sigma}_{2}$ content, contrary to the model of Massuyeau et al. (2015). Details on calculatio a and compositions of the melt endmembers are provided in Section 3 of the Supplemenu ry nformation.

In addition to melt composition, melt frotion can also be determined using volatile partitioning. $\mathrm{CO}_{2}$ is treated as highly incomp. t'sle, i.e. entirely residing in the melt (e.g. Dasgupta et al., 2013). The $\mathrm{H}_{2} \mathrm{O}$ content of he melt is constrained using partition coefficients for nominally anhydrous minerals/hydre as ilicace melt systems from Hirschmann et al. (2009) and Novella et al. (2014). No' that $\mathrm{H}_{2} \mathrm{O}$ solubility does not significantly differ between $\mathrm{CO}_{2}$-poor basaltic melts an. ${ }^{1} \mathrm{CO}_{2}$-rich, low-SiO ${ }_{2}$ melts (Dasgupta et al., 2013; Moussallam et al., 2016). Thus, the .'vss fraction of melt, $F_{m}^{M e l t}$, can be calculated either from $\mathrm{CO}_{2}$ partitioning

$F_{m}^{M e l t, 1}=\frac{C_{C O_{2}}^{B u l k}}{C_{C O_{2}}^{M e l t}}$

or from $\mathrm{H}_{2} \mathrm{O}$ partitioning

$F_{m}^{M e l t, 2}=\frac{\frac{C_{\mathrm{H}_{2} \mathrm{O}}^{\mathrm{Bullk}}}{\mathrm{C}_{\mathrm{H}_{2} \mathrm{O}}^{M e l t}}-D_{\mathrm{H}_{2} \mathrm{O}}^{\text {Peridotite } / \text { Melt }}}{1-D_{\mathrm{H}_{2} \mathrm{O}}^{\text {Peridotite } / \text { Melt }}}$.

$C_{\mathrm{CO}_{2}}^{\mathrm{Bulk}}$ and $\mathrm{C}_{\mathrm{H}_{2} \mathrm{O}}^{\mathrm{Bulk}}$ are the mass fractions of $\mathrm{CO}_{2}$ and $\mathrm{H}_{2} \mathrm{O}$ in bulk peridotite rock in wt\%, respectively. $C_{\mathrm{CO}_{2}}^{\mathrm{Melt}}$ and $\mathrm{C}_{\mathrm{H}_{2} \mathrm{O}}^{\mathrm{O} \text { lt }}$ are the mass fractions of $\mathrm{CO}_{2}$ and $\mathrm{H}_{2} \mathrm{O}$ in melt in wt\%, respectively, converted from the molar fractions $X_{\mathrm{CO}_{2}}^{\mathrm{Melt}}$ and $\mathrm{X}_{\mathrm{H}_{2} \mathrm{O}}^{\mathrm{O} \text { elt }}$ calculated above. $D_{\mathrm{H}_{2} \mathrm{O}}^{\text {Peridotite/Melt }}$ is the pressure-dependent partition coefficient of $\mathrm{H}_{2} \mathrm{O}$ between peridotite and melt, calculated as follows:

$D_{\mathrm{H}_{2} \mathrm{O}}^{\text {Peridotite } / \text { Melt }}=X_{\mathrm{Ol}} D_{\mathrm{H}_{2} \mathrm{O}}^{\text {Ol/Melt }}+X_{\mathrm{Opx}} D_{\mathrm{H}_{2} \mathrm{O}}^{\text {Opx } / \text { melt }}+X_{C p x} D_{\mathrm{H}_{2} \mathrm{O}}^{\text {Cpx/Melt }}+X_{G r t} D_{\mathrm{H}_{2} \mathrm{O}}^{\text {Grt } / \text { melt }}+X_{S p} D_{\mathrm{H}_{2} \mathrm{O}}^{\text {Sp }}$, 
where $X_{O l}, X_{O p x}, X_{C p x}, X_{G r t}$ and $X_{S p}$ are the modal proportions of olivine, orthopyroxene, clinopyroxene, garnet and spinel, respectively, calculated from Hirschmann et al. (2009), and $D_{\mathrm{H}_{2} \mathrm{O}}^{\text {Ol/Melt }}, D_{\mathrm{H}_{2} \mathrm{O}}^{\mathrm{O} x \mathrm{Melt}}, D_{\mathrm{H}_{2} \mathrm{O}}^{\mathrm{Cpx} / \text { Melt }}, D_{\mathrm{H}_{2} \mathrm{O}}^{\text {Grt/Melt }}$ and $D_{\mathrm{H}_{2} \mathrm{O}}^{\text {Sp }}$ elt are the partition coefficients of $\mathrm{H}_{2} \mathrm{O}$ of olivine, orthopyroxene, clinopyroxene, garnet and spinel, respectively, in equilibrium with melt, calculated from Hirschmann et al. (2009) and Novella et al. (2014) (see details in Section 4 of the Supplementary Information). Hence, two different melt fractions can be obtained when varying $\mathrm{C}_{\mathrm{CO}_{2}}^{\mathrm{Melt}}$ and $\mathrm{C}_{\mathrm{H}_{2} \mathrm{O}}^{\mathrm{Melt}}$ independently following Eqs. (5) and (6), which should converge to an identical value. The optimizations of melt composition and melt fraction are thus performed concomitantly in such a way that $\left(a_{\mathrm{SiO}_{2}}^{\mathrm{Melt}_{1}}-a_{\mathrm{SiO}_{2}}^{\mathrm{Melt}_{2}}\right)^{2}+$ $100\left(F_{m}^{\text {Melt }, 1}-F_{m}^{\text {Melt,2 }}\right)^{2}(8)$ is minimized (see details about the optimization procedure in Section 5 of the Supplementary Information).

For some pressure-temperature-bulk rock compositio a conditions, melt composition cannot be unequivocally predicted and MAGLAB yields two ćls inct solutions, carbonate-rich and silicate-rich. This numerical feature, which relies on the Margules formalism used to

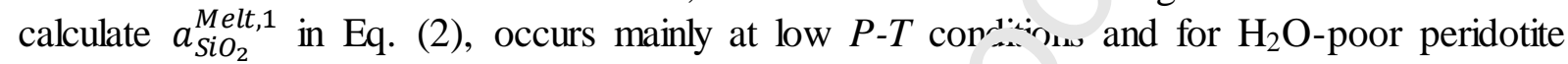
systems. It is indicative of the non-ideality in the $m^{\prime} x_{i} \cdot \sigma$ jetween silicate and carbonate components at these conditions, which ultimately resul in immiscibility (Dasgupta et al., 2013; Massuyeau et al., 2015). However, we exper t on 'y one liquid to be stabilized because immiscibility is not reported in most of the experin ntal studies of melting in peridotitic compositions (Martin and Schmidt, 2013; Ham „uda and Keshav, 2015). Since silicate-rich melts are favored at high $T$ and low $P$ and, cc $n-r_{s} f_{1}$, carbonate-rich melts are favored at low $T$ and high $P$, we use a pressure-depend _t 1 rmulation to determine, at a given $P$, the most probable stable melt composition betv, en these two distinct compositional solutions as a function of $T$ (Fig. S5). 


\subsection{Calculation of the electrical conductivity for model mantle peridotite}

The second part of MAGLAB calculates the bulk electrical properties of mantle rocks with melt composition and melt fraction equilibrated at $P, T$ and bulk rock $\mathrm{CO}_{2}$ and $\mathrm{H}_{2} \mathrm{O}$ content. As volatile-bearing melts interconnect in mantle rocks at any melt fraction (Gardés et al., 2020), the bulk electrical conductivity of partially molten mantle peridotite is a combination of the conductivity of the rock and the conductivity of the melt weighted by melt fraction.

The electrical conductivity of melt is calculated following the model of Sifré et al. (2014, 2015) for $\mathrm{CO}_{2}$ - and $\mathrm{H}_{2} \mathrm{O}$-bearing melts

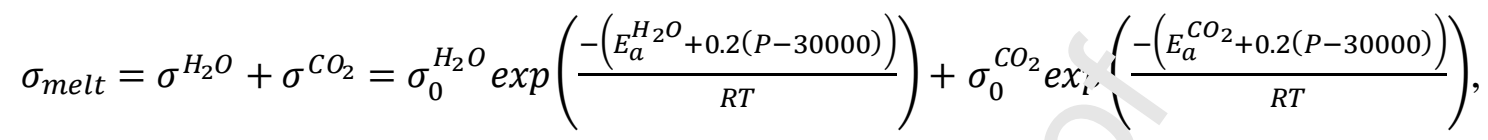

where $P$ is the pressure (bar), and $\sigma_{0}$ and $E_{A}$ are the rex ponential factor $\left(\mathrm{S} \mathrm{m}^{-1}\right)$ and the activation energy $\left(\mathrm{J} \mathrm{mol}^{-1}\right)$, respectively, for the $\mathrm{t}$.' A Arrhenius laws describing the contributions of the hydrous silicate component $\left(\sigma^{\mathrm{H}_{2} \mathrm{l}}\right)$ ar 1 the carbonate component $\left(\sigma^{\mathrm{CO}_{2}}\right)$

$\ln \left(\sigma_{0}^{\mathrm{H}_{2} \mathrm{O}}\right)=4.5410^{-5} E_{a}^{\mathrm{H}_{2} \mathrm{O}}+5.5607$ with $E_{a}^{\mathrm{H}_{2} \mathrm{O}}=28 / 74 \exp \left(-0.3880 C_{\mathrm{H}_{2} \mathrm{O}}^{\mathrm{Melt}}\right)+73029,(10)$

and $\ln \left(\sigma_{0}^{\mathrm{CO}_{2}}\right)=5.5010^{-5} E_{a}^{\mathrm{CO}_{2}}+5.795 f \quad$ w th $\quad E_{a}^{\mathrm{CO}_{2}}=789166 \exp \left(-0.1808 C_{\mathrm{CO}_{2}}^{\mathrm{Melt}^{2}}\right)+32820$.

This law is valid for $C_{\mathrm{CO}_{2}}^{\mathrm{Melt}}$ from 0 to $\sim, 0 \mathrm{wt} \%$ and $C_{\mathrm{H}_{2} \mathrm{O}}^{\mathrm{Melt}}$ from 0 to $\sim 10 \mathrm{wt} \%$.

The electrical conductivity of the nlid rock is assumed to be controlled by the conductivity of olivine. We use the model of Iaraés et al. (2014) which provides conductivity as a function of temperature and $\mathrm{H}_{2} \mathrm{O}$ conten

$$
\begin{aligned}
& \sigma_{o l}= \\
& 10^{5.07} \exp \left(-\frac{239000}{R T}\right)+1{ }^{12734} \exp \left(-\frac{144000}{R T}\right)+ \\
& 10^{-1.17}\left(10000 C_{\mathrm{H}_{2} \mathrm{O}}^{\text {Oline }}\right) \exp \left(-\frac{89000-2080\left(10000 C_{\mathrm{H}_{2} \mathrm{O}}^{\text {Oline }}\right)^{1 / 3}}{R T}\right)
\end{aligned}
$$

$\mathrm{C}_{\mathrm{H}_{2} \mathrm{O}}^{\text {Oline }}$, the mass fraction of water in olivine in $\mathrm{wt} \%$, is given by

$C_{\mathrm{H}_{2} \mathrm{O}}^{\text {Olivine }}=\mathrm{C}_{\mathrm{H}_{2} \mathrm{O}}^{\mathrm{Melt}} D_{\mathrm{H}_{2} \mathrm{O}}^{\text {Ol/Melt }}$

where $D_{\mathrm{H}_{2} \mathrm{O}}^{\text {Ol/Melt }}$ is the partition coefficient of $\mathrm{H}_{2} \mathrm{O}$ between olivine and melt (see Section 4 of the Supplementary Information).

Following Sifré et al. (2014), the mixing model for calculating the bulk conductivity of partially molten mantle peridotite is taken as a combination of an Hashin-Shtrikman upper bound (HS+) mixing model and a tube mixing model (e.g. Schmeling, 1986) 
$\sigma_{\text {bulk }}=\frac{1}{2}\left(\left(\frac{F_{v}^{\text {Melt }}}{\sigma_{\text {melt }}+2 \sigma_{\text {melt }}}+\frac{\left(1-F_{v}^{M e l t}\right)}{\sigma_{o l}+2 \sigma_{\text {melt }}}\right)^{-1}-2 \sigma_{\text {melt }}\right)+\frac{1}{2}\left(\frac{1}{3} F_{v}^{M e l t} \sigma_{m e l t}+\left(1-F_{v}^{M e l t}\right) \sigma_{o l}\right),(14)$

where the volume fraction of melt $F_{v}^{M e l t}$ is given by

$F_{v}^{M e l t}=\frac{\left(\frac{F_{m}^{M e l t}}{d_{m e l t}}\right)}{\left(\frac{F_{m}^{M e l t}}{d_{\text {melt }}}+\frac{\left(1-F_{m}^{M e l t}\right)}{d_{\text {olivine }}}\right)}$

Olivine density $d_{\text {olivine }}$ is taken as 3.34 (average of values give:i for olivine in both spinel and garnet peridotite in Table 1a of Lee (2003)). Following s.jre et al. (2014), melt density $d_{\text {melt }}$ is calculated as

$d_{\text {melt }}=\frac{C_{\mathrm{H}_{2} \mathrm{O}}^{\mathrm{Melt}}}{100} d_{\mathrm{H}_{2} \mathrm{O}}+\frac{2 C_{\mathrm{CO}_{2}}^{\mathrm{Melt}}}{100} d_{\mathrm{CO}_{2}}+\left(1-\frac{C_{\mathrm{H}_{2} \mathrm{O}}^{\mathrm{Melt}}+2 C_{\mathrm{CO}}^{\mathrm{Melt}}}{100}\right) d_{h_{\text {asal }}}$ (16)

with $d_{\mathrm{H}_{2} \mathrm{O}}=1.4, d_{\mathrm{CO}_{2}}=2.4$, and $d_{\text {basalt }}=2.8$. 


\section{MAGLAB: comparison with previous models}

In contrast to models developed for dry and hydrous silicate magmatic systems (e.g., MELTS family: Ghiorso and Sack (1995), Ghiorso et al. (2002), Gualda et al. (2012); COMAGMAT: Ariskin (1999); PerpleX: Connolly (2005)), only a few models allow for calculating the composition and fraction of melts derived from peridotite melting in the presence of $\mathrm{CO}_{2}$ and $\mathrm{H}_{2} \mathrm{O}$, and their range of applicability is limited, especially in terms of composition and pressure. The model of Ghiorso and Gualda (2015) addresses silicate melts with limited dissolved $\mathrm{CO}_{2}$ and $\mathrm{H}_{2} \mathrm{O}$ components and is not relevant to investigating carbonate-rich melts with $\mathrm{CO}_{2}$ content $>\sim 10$ wt $\%$ or $\mathrm{P}>3 \mathrm{GPa}$. Calculation of melt composition is limited to $\mathrm{CO}_{2}, \mathrm{H}_{2} \mathrm{O}$ and $\mathrm{SiO}_{2}$ oxides in the model of Dasgupta et al. (2013), $\mathrm{CO}_{2}$ and $\mathrm{H}_{2} \mathrm{O}$ in the model of Hirschmann (2010), and to $\mathrm{CO}_{2}$ only in the models of Dasgupta et al. (2007) and Ghosh et al. (2014). Furthermore, the pre sure range of application is $\leq 5$ GPa for the models of Dasgupta et al. (2007, 2013), Hirschma.' (2010) and Ghiorso and Gualda (2015), and >10 GPa for the model of Ghosh et al. 2014). Thus, none of these models allows calculations at pressures between 5 and $10 \mathbf{C}$ a. The model of Massuyeau et al. (2015) does not allow varying bulk rock $\mathrm{CO}_{2}$ and $\mathrm{H}_{-} \mathrm{O}$ ontents independently. To date, MAGLAB is the model simulating the widest ranges of emperature and pressure, from $~ 900$ to $1700^{\circ} \mathrm{C}$ and from $\sim 2$ to $10 \mathrm{GPa}$ (i.e., from $\sim 60$ to $\sim 00 \mathrm{~km}$ depth). It allows composition calculations in $\mathrm{SiO}_{2}-\mathrm{TiO}_{2}-\mathrm{Al}_{2} \mathrm{O}_{3}-\mathrm{FeO}-\mathrm{CaO}-\mathrm{MgO}-\mathrm{Na} 2 \mathrm{C} \cdot{ }_{2} \mathrm{O}-\mathrm{H}_{2} \mathrm{O}-\mathrm{CO}_{2}$ space where, notably, $\mathrm{CO}_{2}$ and $\mathrm{H}_{2} \mathrm{O}$ are independent variables.

A key feature of mantle-relevant me itit ${ }_{0}$ is the abrupt transition from carbonatitic melts $\left(<15 \mathrm{wt} \% \mathrm{SiO}_{2}\right)$ to silicate-rich $\mathrm{m}-\mathrm{H} . \quad\left(-30 \mathrm{wt} \% \mathrm{SiO}_{2}\right)$, as illustrated by experimental data at e.g. 3 and $5 \mathrm{GPa}$ where the tra. ${ }^{\circ}$.on occurs at $\sim 1350^{\circ} \mathrm{C}$ and $\sim 1450^{\circ} \mathrm{C}$ respectively (Fig. 4A-B). At 3 and 5 GPa, both Dasguptw et al. (2007) and Dasgupta et al. (2013) do not reproduce this abrupt transition. At 5 . Pa, the model of Dasgupta et al (2013) yields an almost linear positive evolution $r_{1}$ the $\mathrm{SiO}_{2}$ content with increasing temperature corresponding to a near ideal syst_.n. $\therefore 3 \mathrm{GPa}$, the model of Dasgupta et al. (2007) fails to predict the formation of carbonate melts at low temperatures (Fig. 4A). On the other hand, MAGLAB captures this chemic a' shit at 3 and $5 \mathrm{GPa}$, as does the model of Massuyeau et al. (2015) (Fig. 4A-B). In contra + MAGLAB produces a smoother transition from carbonaterich melts to silicate-rich me an at higher pressures, as observed experimentally at e.g. 7 and $10 \mathrm{GPa}$, which is not we, cal tured in the model of Massuyeau et al. (2015) (Fig. 4C-D).

Thus, MAGLAB i irly well reproduces the wide range of mantle-relevant, $\mathrm{CO}_{2} \pm \mathrm{H}_{2} \mathrm{O}$ bearing melts. It applies to pressures and temperatures covering most of Earth's upper mantle regions subject to $\left(\mathrm{CO}_{2}+\mathrm{H}_{2} \mathrm{O}\right.$ )-assisted melting (Wallace and Green, 1988; Foley et al., 2009) which, away from ridges, starts at depths $>\sim 60 \mathrm{~km}$ beneath mature to old oceanic lithosphere (Fig. 5). Moreover, in addition to melt composition, MAGLAB also allows the calculation of melt fraction and corresponding bulk rock electrical conductivity. It should be noted, however, that MAGLAB calculations are valid as long as oxygen fugacity stabilizes carbonates as important carbon species, i.e. in upper mantle regions, estimated between $\sim 60$ $\mathrm{km}$ and $\sim 300 \mathrm{~km}$ depth (Wallace and Green, 1988; Hirschmann, 2010; Rohrbach and Schmidt, 2011; Stagno et al., 2013; Gaillard et al., 2015; Yaxley et al., 2017; Dasgupta, 2018; Eguchi and Dasgupta, 2018; Moussallam et al., 2019; Gardés et al., 2020). Furthermore, calculations are not possible at zero bulk rock $\mathrm{CO}_{2}$ content and in a set of extreme $P$-T-volatile content conditions, e.g. at low $P<5 \mathrm{GPa}$ in very hot mantle with potential temperature $T_{P}>1500-1600^{\circ} \mathrm{C}$, or even at higher pressures for bulk rock $\mathrm{CO}_{2}-\mathrm{H}_{2} \mathrm{O}$ contents >0.1-0.2 wt\% and with $\mathrm{H}_{2} \mathrm{O} / \mathrm{CO}_{2}$ molar ratio $>10-20$ (see details in Section 6 of the 
Supplementary Information; MAGLAB hyperlink: http://calcul-isto.cnrsorleans.fr/apps/maglab/). 


\section{MAGLAB simulations of oceanic and cratonic mantle}

We used MAGLAB to calculate melt composition, melt fraction and associated electrical conductivity of the upper mantle in oceanic and cratonic settings, with focus on three main parameters: lithospheric thickness, mantle potential temperature $\left(T_{P}\right)$, and mantle $\mathrm{CO}_{2}-\mathrm{H}_{2} \mathrm{O}$ content. It should be noticed that the following results correspond to equilibrium melt fractions and compositions, and thus do not consider dynamic phenomena such as melt migration, melt accumulation and depletion processes. The position of the base of the lithosphere, i.e. LAB depth, can be approximately located within the thermal boundary layer where a time-dependent thermal transition from the conductive to fully convecting upper mantle occurs (Parsons and McKenzie, 1978; McKenzie and Bickle, 1988; Jaupart and Mareschal, 1999; McKenzie et al., 2005; An et al., 2015; Priestley et al., 2019). It is hereafter defined at the base of this thermal boundary layer (Jaupart an l Mareschal, 1999; An et al., 2015) as the depth where mantle temperature is lowered by $10^{\circ} \mathrm{C}$ from the temperature of the adiabatic geotherm. Although we acknowledge that our defi itio for identifying the base of the lithosphere is somewhat simplistic in comparison with w w omplex and diffuse nature of the lithosphere-asthenosphere transition, this method prov. tes a reasonable estimation of the lithospheric thickness, with the advantage of being - nnsistent when applied to different tectonic settings.

Fig. 5 reports MAGLAB simulations for an 'mbient oceanic upper mantle with average volatile content, i.e. 140 wt ppm $\mathrm{CO}_{2}-2 \Delta \mathrm{J}$ wt ppm $\mathrm{H}_{2} \mathrm{O}$ (Le Voyer et al., 2017), and a potential temperature $T_{P}$ of $1350^{\circ} \mathrm{C}$ (thermal ... del G13R1350 from Grose and Afonso (2013)). The most striking result is the $\mathrm{c}^{\prime}, \mathrm{nu}$ ist in melt composition and melt fraction between the asthenosphere and the lithosphere.

In the asthenosphere, from $\mathrm{inc}_{c}^{\text {rh }}$ to low pressure, both melt $\mathrm{SiO}_{2}$ content and melt fraction increase while melt $\mathrm{CO}_{2} \sim$-ntc..t and bulk electrical conductivity decrease. The evolution of melt composition is cons st $n$ t with the increase in silica activity with decreasing pressure (Carmichael et al., 19.'0; Massuyeau et al., 2015), as well as with the systematic complementarity of melt $\mathrm{CO}_{2}$ cors ant and melt $\mathrm{SiO}_{2}$ content observed experimentally (e.g. Gudfinnsson and Presnall, 2 ¿ns, Dasgupta et al., 2007, 2013; Ghosh et al., 2014). At around $300 \mathrm{~km}$ depth, a fraction $\mathrm{c}^{\mathrm{f}} \sim(.05 \mathrm{wt} \%(0.06 \mathrm{vol} \%)$ of carbonatitic melt is produced, with $\mathrm{SiO}_{2}, \mathrm{CO}_{2}$ and $\mathrm{H}_{2} \mathrm{O}$ ronu nts of $\sim 11,31$ and $4 \mathrm{wt} \%$, respectively, and mantle electrical

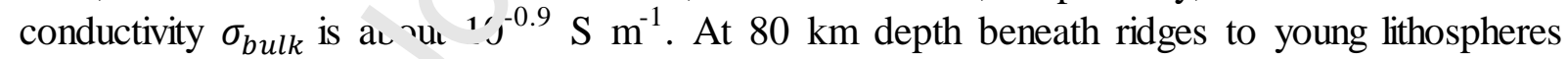
$(<\sim 10 \mathrm{Ma})$, a fraction of $0.24 \mathrm{wt} \%(0.30 \mathrm{vol} \%)$ of silicate-rich melt is produced, with $\mathrm{SiO}_{2}$, $\mathrm{CO}_{2}$ and $\mathrm{H}_{2} \mathrm{O}$ contents of $\sim 42,6$ and $2 \mathrm{wt} \%$, respectively, and $\sigma_{\text {bulk }}$ is $\sim 10^{-1.4} \mathrm{~S} \mathrm{~m}^{-1}$. Noteworthy, for constant volatile content in the source, variations reported in mantle electrical conductivity are buffered by the opposite effects of melt composition and melt fraction: for example, volatile contents increase $\sigma_{\text {bulk }}$, but smaller melt fractions decrease it.

The evolution strongly differs beneath mature to old lithospheres $(>\sim 50 \mathrm{Ma})$, where both melt $\mathrm{SiO}_{2}$ content and melt fraction drop while melt $\mathrm{CO}_{2}$ content rises in the lithosphere. These abrupt changes in melt composition and melt fraction from asthenosphere to lithosphere are a direct consequence of the abrupt change in temperature (Fig. 4), and may be accompanied by a slight increase in bulk electrical conductivity (e.g., near LAB depth at 120$125 \mathrm{~km}$ in an ambient oceanic upper mantle with average volatile content; see profile "Ambient" in Fig. 6F). At $80 \mathrm{~km}$ depth in $70 \mathrm{Ma}$ oceanic lithosphere, a fraction of $0.03 \mathrm{wt} \%$ $\left(0.05\right.$ vol\%) of carbonatitic melt is produced, with $\mathrm{SiO}_{2}, \mathrm{CO}_{2}$ and $\mathrm{H}_{2} \mathrm{O}$ contents of $\sim 2,42$ and $2.5 \mathrm{wt} \%$, respectively, and $\sigma_{\text {bulk }}$ is about $10^{-1.45} \mathrm{~S} \mathrm{~m}^{-1}$. Note that melting stops when crossing the $\mathrm{CO}_{2}-\mathrm{H}_{2} \mathrm{O}$-bearing peridotite solidus above $60-70 \mathrm{~km}$ depth beneath mature to old 
lithospheres ( $\mathrm{P}<\sim 2 \mathrm{GPa}$ and $\mathrm{T}<\sim 930-1100^{\circ} \mathrm{C}$; grey areas in Fig. 5, see also Fig. 2). Then, mantle electrical conductivity is mainly controlled by olivine, with values $<10^{-2} \mathrm{~S} \mathrm{~m}^{-1}$ (Gardés et al., 2014).

The base of mature to old lithospheres thus corresponds to a region where melt fraction is maximum. At the vicinity of the $\mathrm{LAB}$ beneath $>\sim 50 \mathrm{Ma}$ lithospheres, i.e. at 120$125 \mathrm{~km}$ depth, a fraction of $0.14 \mathrm{wt} \%(0.17 \mathrm{vol} \%)$ of silicate-rich melt is present, with $\mathrm{SiO}_{2}$, $\mathrm{CO}_{2}$ and $\mathrm{H}_{2} \mathrm{O}$ contents of $\sim 35,10$ and $3 \mathrm{wt} \%$, respectively, and mantle electrical conductivity $\sigma_{\text {bulk }}$ is about $10^{-1.2} \mathrm{~S} \mathrm{~m}^{-1}$.

Melt composition, melt fraction and mantle electrical conductivity profiles in $70 \mathrm{Ma}$ oceanic lithosphere for various $T_{P}$ and volatile contents are reported in Figs 6 and 7, respectively. In Fig. 6, we report calculations for a mantle with average volatile content and various $T_{P}$ of $1300,1350,1400$ and $1450^{\circ} \mathrm{C}$ (G13R1300, G13R1350, G13R1400 and G13R1450 models from Grose and Afonso (2013)), correspo. iding to cold, ambient, hot, and hotspot settings, respectively. Near the LAB, at $\sim 115-125 \mathrm{~km}$ c $\cdot$ nth, MAGLAB yields melt compositions ranging from $\sim 7$ to $40 \mathrm{wt} \% \mathrm{SiO}_{2}, 37$ to $5 \mathrm{wt} \% \mathrm{CO}_{2}$ and 4 to $3 \mathrm{wt} \% \mathrm{H}_{2} \mathrm{O}$ from cold mantle $\left(\sim 1350^{\circ} \mathrm{C}\right.$ at $\mathrm{LAB}$ depth) to hotspot-like $1 \mathrm{~m}$ ' $\mathrm{uc}\left(\sim 1500^{\circ} \mathrm{C}\right.$ at LAB depth), respectively (Fig. 6A-D). Melt fraction ranges between $0 . \mathrm{L}^{\prime} \mathrm{z}$. ad $0.26 \mathrm{wt} \%(0.05-0.32$ vol\%) within the same temperature interval (Fig. 6E), while $\sigma_{b^{\prime}{ }^{\prime} \text { ' }}$ slightly increases from $10^{-1.15}$ to $10^{-1.06} \mathrm{~S} \mathrm{~m}^{-1}$ approximately (Fig. 6F). Note that mos of he variations in composition and melt fraction occurs between cold and ambient settings si re, e.g., the range of $\mathrm{SiO}_{2}$ content reduces to 35-40 wt\% from ambient to hotspr. ettings. The electrical conductivity remains, however, rather constant because the large 1 ria ion in melt composition, changing from silicate-rich in hotspot settings to carbor.. itic in cold settings, is compensated by a large decrease in melt fraction.

In Fig. 7, mantle $\mathrm{CO}_{2}$ and $\mathrm{H}_{-} \mathrm{O}$ contcnts are varied around their average contents in an ambient mantle: $50-80,140-240$ and $\because ? 0-720$ wt ppm $\mathrm{CO}_{2}-$ wt ppm $\mathrm{H}_{2} \mathrm{O}$, corresponding to depleted, average, and enriched $n n_{1}$ is source, respectively. Near LAB depth, depleted to enriched sources produce silicate $-\mathrm{i} \cdot \mathrm{h}$ melts with an almost constant melt $\mathrm{SiO}_{2}$ content of around $35 \mathrm{wt} \%$, a slightly varin $\mathrm{b}^{-}$melt $\mathrm{CO}_{2}$ content ranging from 11 to $8 \mathrm{wt} \%$, and a more

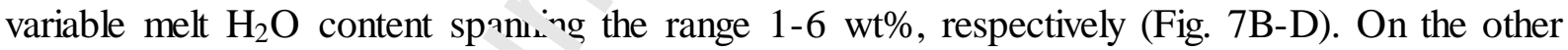
hand, melt fraction dramatirally increases from about 0.04 to 0.54 wt\% ( 0.05-0.68 vol\%) from depleted to enrich : suarces, respectively, illustrating the strong dependence of melt fraction on volatile $\mathrm{c} \backslash \mathrm{nte}_{\mathrm{t}}$ nt (Fig. 7E). As a consequence, contrary to temperature variations, the large increase in 1 alt fraction together with variations in melt volatile content from depleted to enriched watile content induce a large variation in electrical conductivity, from $10^{-1.54}$ to $10^{-0.76} \mathrm{~S} \mathrm{~m}^{-1}$ (Fig. 7F).

Importantly, at any of the temperature and bulk rock volatile content simulated, no transitional melts with intermediate compositions between silicate-rich and carbonatitic melt, i.e. carbonated silicate melts with $\mathrm{SiO}_{2}$ content within the range 15-35 wt\%, are obtained near the LAB in oceanic mantle. In contrast, the asthenosphere beneath extremely thick continental lithosphere, such as in undisturbed cratonic regions, can give rise to melts with low to intermediate $\mathrm{SiO}_{2}$ contents at realistic pressure-temperature-volatile content conditions (Fig. 8B). We performed MAGLAB calculations along a typical cratonic geotherm, with $T_{P}=$ $1350^{\circ} \mathrm{C}$ and considering various bulk rock volatile contents as previously described (see details about geotherm in Figs 8A-S6 and their caption). Near the LAB, at $210 \mathrm{~km} \mathrm{depth,}$ while depleted to average mantle sources produce carbonatitic melts with < 15 wt $\% \mathrm{SiO}_{2}$, $>\sim 30$ wt $\% \quad \mathrm{CO}_{2}$ and $<\sim 5 \quad \mathrm{wt} \% \quad \mathrm{H}_{2} \mathrm{O}$, enriched sources produce kimberlitic melt with intermediate $\mathrm{SiO}_{2}$ and $\mathrm{CO}_{2}$ contents of $\sim 22$ and $\sim 18 \mathrm{wt} \%$, respectively, and an $\mathrm{H}_{2} \mathrm{O}$ content of 
about 9 wt\% (Fig. 8B-D). Noteworthy, similar kimberlitic, transitional melts are calculated in the case of a $\mathrm{CO}_{2}$-average and $\mathrm{H}_{2} \mathrm{O}$-enriched mantle (i.e., with 140 wt ppm $\mathrm{CO}_{2}-720$ wt ppm $\mathrm{H}_{2} \mathrm{O}$; Fig. 8B). As with oceanic mantle, melt fraction at LAB depth beneath cratonic settings largely increases from depleted to enriched sources, from $\sim 0.01$ to $0.24 \mathrm{wt} \%(0.02-0.31$ vol\%), which, coupled with variations in melt volatile content, induces a large increase in electrical conductivity, from about $10^{-1.4}$ to $10^{-0.5} \mathrm{~S} \mathrm{~m}^{-1}$ (Fig. 8E-F). 


\section{Discussion}

\subsection{Linking the diversity of mantle-sourced intraplate magmatism to lithosphere thickness}

The composition of intraplate magmas generally relates to the tectonic setting in which they were produced, with mid-ocean ridge basalts (MORB) sampled around oceanic ridges, OIBs mainly erupted over ocean floors away from plate boundaries, and kimberlites quasi-exclusively observed on continental shields, mainly on-craton. These systematics indicate that geodynamic context exerts a primary control on the compositional spectrum of intraplate magmatism. One of the main features varying between different tectonic settings is lithosphere thickness, being thin near oceanic ridges and thick beneath most cratons. It is therefore reasonable to assume that variations in lithosp. re thickness may generate variations in primitive melt composition, without invoking '15 compositional variations in the mantle sources (le Roex, 1986; Ringwood et al., 1992; C 'df nnsson and Presnall, 2005; Tappe et al., 2013, 2016, 2018; Grose and Afonso, 20 9; 3audouin and Parat, 2020). A critical effect of lithosphere thickness on the com osiun of mantle-derived intraplate alkaline basalts and basalts (i.e., melts with $>40 \mathrm{w}^{+} / \mathrm{c} \quad \mathrm{si}_{2}$ ) has been outlined in previous geochemical studies: with increasing lithospheric $\mathrm{u}_{\mathrm{i}} \mathrm{r} \mathrm{kr}$ ess, the final equilibrium pressure before melt extraction increases, lowering the degre ot nelting and thus lowering melt $\mathrm{SiO}_{2}$ and $\mathrm{Al}_{2} \mathrm{O}_{3}$ contents, while increasing $\mathrm{MgO}$ and $\mathrm{er} J$ contents (Haase, 1996; Humphreys and Niu, 2009; Dasgupta et al., 2010; Niu et al 20i.; Davies et al., 2015; Zhang et al., 2017; Guo et al., 2020). Furthermore, a nat ras example for the continuum of melt composition ranging from kimberlitic to OIB-type alka:"e basaltic was described in Tappe et al. (2007), where changes in magma compositicn through time are explained as a function of significant lithosphere thinning of a single cratonic $\iota^{\prime}$ 'xck. Excluded from this concept are lamproites and other highly potassic magma types, a, ell as intrusive carbonatites, because these intraplate magmas have typically experienc $\lrcorner$ vanable contributions from strongly metasomatized nonperidotitic components of the ra. ${ }^{4} \mathrm{le}$ lithosphere, or they can be highly differentiated in nature (Becker and le Roex, 2006; P i $^{+}$et al., 2008; Doucelance et al., 2010; Weidendorfer et al., 2017; Tappe et al., 2017).

Here, we use $\triangle A C A B$ to simulate the effect of varying lithosphere thickness on primitive melt compos.tion oy calculating volatile-bearing melt compositions in equilibrium with peridotite near the $\mathrm{JB}$ and comparing them with corresponding erupted magmas. We performed MAGLAB simulations by varying LAB depth as a function of the tectonic setting (see $P-T$ conditions in Fig. S7), and considering a single homogeneous mantle source with 140 wt ppm $\mathrm{CO}_{2}$ and 240 wt ppm $\mathrm{H}_{2} \mathrm{O}$ on average (Le Voyer et al., 2017). Using the $\mathrm{SiO}_{2}$ content as a relevant proxy for the compositional variability of intraplate magmatism in Fig. 9, the composition of erupted basaltic magmas such as MORBs and OIBs with $\mathrm{SiO}_{2}>45 \mathrm{wt} \%$ are well reproduced by MAGLAB beneath the thinnest and youngest oceanic lithospheres with LAB depths $<60 \mathrm{~km}$. Primitive alkaline magmas such as melilitites, nephelinites, basanites and silica-poor OIBs with 35-45 wt\% $\mathrm{SiO}_{2}$ are reproduced by MAGLAB beneath the thickest oceanic lithospheres away from modern spreading centers, as well as beneath young or rejuvenated continents with LAB depths ranging from around 60 to $125 \mathrm{~km}$ (Fig. 9). Interestingly, rare occurrences of alnoitic $\mathrm{CO}_{2}$-rich intrusions with $\mathrm{SiO}_{2} \sim 36$ wt\% have been reported at the surface of the $\sim 120$-km-thick lithosphere of the Ontong Java Plateau (Neal and Davidson, 1989; Simonetti and Neal, 2010; Smart et al., 2019), and this $\mathrm{SiO}_{2}$ content is well reproduced in our MAGLAB calculations at such $\mathrm{LAB}$ depth (i.e., $\sim 35 \mathrm{wt} \% \mathrm{SiO}_{2}$; Figs 5B, 
9). In addition, MAGLAB predicts mantle-derived melts with a $\mathrm{SiO}_{2}$ content of $\sim 40 \mathrm{wt} \%$ beneath $\sim 90-\mathrm{km}$-thick lithosphere, similar to the petit-spot magmas erupted directly from the asthenospheric source located beneath the flexed sections of the oceanic lithosphere prior to entering subduction zones (Hirano et al., 2006; Matsuno et al., 2010; Machida et al., 2017; Sato et al., 2018). Generation of kimberlites also fits well into this hypothesis, with primary melts with 15-35 wt $\mathrm{SiO}_{2}$ being produced at $>120$ to $\sim 200 \mathrm{~km}$ depth beneath continental shields including cratons (Fig. 9; Gudfinnsson and Presnall, 2005; Brey et al., 2009; Foley et al., 2009; Stamm and Schmidt, 2017; Tappe et al., 2017; Giuliani et al., 2019; Sun and Dasgupta, 2019). Such carbonated silicate melt compositions can be equilibrated beneath typical LAB depths of undisturbed cratons (i.e., 180-250 km) in warmer thermal conditions, with $T_{P}>\sim 1350-1400^{\circ} \mathrm{C}$, equivalent to the peripheries of modern mantle plumes or Early Proterozoic and Archean ambient upper mantle conditions (Korenaga, 2008; Davies, 2009; Ganne and Feng, 2017; Aulbach and Arndt, 2019; Sun and Dasgupta, 2020; see also Fig. 6B). However, many kimberlite occurrences at the Earth's s.r.ace were emplaced between 50-250 Ma (Tappe et al., 2018), a period for which the Earth's mantle presented a thermal regime similar to present-day (difference in $T_{P}<40-50^{\circ} \mathrm{C}$; .'ore raga, 2008; Davies, 2009; Ganne and Feng, 2017; Aulbach and Arndt, 2019). Furt ¿en. ore, genetic connections between kimberlite magma generation and mantle plumes are stil $w^{\text {h h }}$.ed (see for example Tappe et al., 2020). Alternatively, primary transitional carbonater ilicate melts can also be produced beneath such undisturbed cratons with higher $\mathrm{H}_{2}{ }^{\prime}$ ) $\mathrm{c}$ intent in the bulk peridotite (e.g., carbonatitic melts equilibrated near the LAB at $210 \mathrm{~km}$ tepth in a mantle source with $140 \mathrm{wt}$ ppm $\mathrm{CO}_{2}-240$ wt ppm $\mathrm{H}_{2} \mathrm{O}$ versus kimberlitic 11 ilts equilibrated in a mantle source with 140 wt ppm $\mathrm{CO}_{2}-720$ wt ppm $\mathrm{H}_{2} \mathrm{O}$; see $\mathrm{Sezt}_{\mathbf{n}}+\mathrm{a}$ a Fig. 8B), as is supported by the experimental work of Stamm and Schr in 12n17). Therefore, our simulations indicate that presence of kimberlitic melts beneath ind , urbed cratons may be related to greater $\mathrm{H}_{2} \mathrm{O}$ enrichment in the mantle source. Similarly, - ither excess temperatures or $\mathrm{H}_{2} \mathrm{O}$ enrichments in the mantle source would explain gene tion of basalts with $>45 \mathrm{wt} \% \mathrm{SiO}_{2}$ beneath strongly disturbed cratons with drastically thi $n t$ uthospheres $(\sim 60-100 \mathrm{~km})$ within our scenario (e.g., East African rift, Wyoming, North Chn; see Aulbach, 2019, and references therein).

The empirical observatio $\mathrm{n}$ that variations in lithosphere thickness primarily govern the compositional diversity of prim. ve mantle-derived magmatism (Gudfinnsson and Presnall, 2005; Tappe et al., 2007) is sully supported by MAGLAB modeling. The compositions of erupted magmas correspr, in those equilibrated at LAB depths (Fig. 9), from where they appear to be extrac $\cdot \mathrm{d}$. Th may explain why low- $\mathrm{SiO}_{2}$ melts such as kimberlites and aillikites are mainly fou. 1 under geologically reasonable conditions on continental shields including cratons, whic boundaries at 150-250 km depths (e.g., Aulbach et al., 2017; Tappe et al., 2018) (Figs 7-9). 


\subsection{Testing of MAGLAB on the petrologically-geophysically constrained Society hotspot}

Mantle geophysical anomalies such as high electrical conductivities and sharp seismic shear-wave velocity reductions have been reported at various locations worldwide, beneath oceanic and continental settings (Evans et al., 2005; Baba et al., 2006, 2010, 2017a; Kawakatsu et al., 2009; Schmerr, 2012; Naif et al., 2013; Tada et al., 2016; Tharimena et al., 2017a,b; Rychert et al., 2019). The presence and role of volatile-bearing melts is indisputable in these regions (Gaillard et al., 2008; Schmerr, 2012; Sifré et al., 2014; Tada et al., 2016; Katsura et al., 2017; Tharimena et al., 2017a,b; Rychert et al., 2019; Gardés et al., 2020). Among them, the Society hotspot in the Pacific Ocean is a good candidate to test MAGLAB since geochemical and geophysical boundary conditions in this $\sim 70$ Myr old oceanic lithosphere are rather well constrained (Müller et al., 2008).

The Society hotspot originates from an ascending plume i.4am et al., 2010) which supplies more heat and higher volatile contents compared wi h th $:$ ambient convecting mantle (Tada et al., 2016). The mantle potential temperature has $v \mathrm{n} \eta \mathrm{n}$ estimated within $1450-1500^{\circ} \mathrm{C}$ (Herzberg and Asimow, 2008). The volatile content of th a narde source has been estimated at $\sim 700$ wt ppm $\mathrm{CO}_{2}$ and 720 wt ppm $\mathrm{H}_{2} \mathrm{O}$ by studyino i: degassing in submarine lavas from the Society hotspot (Aubaud et al., 2005). Avern ye 1 lajor element compositions of nearprimary OIBs erupted at various volcanic centers in the Society Islands have also been assessed, providing an estimation of the major en ment composition of melts produced from the plume beneath the Society hotspot (Dasgl p. ' t al., 2010). Besides, the Society hotspot presents an anomalously strong electrical in' 'na 're, called "Zone A" (Nolasco et al., 1998; Suetsugu et al., 2012; Tada et al., 201 \%. .t extends from the lowest part of the upper mantle to approximately $50 \mathrm{~km}$ below sea leveı. Electrical conductivities above $10^{-1} \mathrm{~S} \mathrm{~m}^{-1}$ are

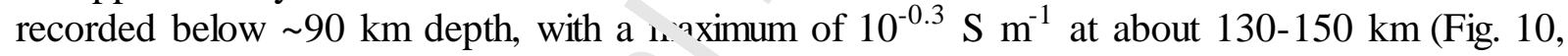
and see profile "Anomaly Zone A" Ir Fig. 11; Tada et al., 2016). This signature is clearly distinct from the electrical condurtivit, ff neighbouring mantle, being about 1 to 2 log units lower (see profile "TIARES" in .ig. 11; Tada et al., 2016).

We performed MACI A? simulations using the pressures, temperatures and volatile contents reported for the Socie, hotspot as inputs, corresponding to the G13R1450 thermal model with $T_{P}=1450^{\circ} \mathrm{C}$ uc $\eta$ urose and Afonso (2013), together with $\sim 700$ wt ppm $\mathrm{CO}_{2}$ and 720 wt $\mathrm{ppm} \mathrm{H}_{2} \mathrm{O}$. $4 \mathrm{r}$ ' nn the $\mathrm{LAB}$ beneath this $\sim 70 \mathrm{Myr}$ old oceanic lithosphere, at approximately $120 \pm 10 \mathrm{ki}$ depth, MAGLAB yields $\sim 1.2$ to $1.5 \mathrm{wt} \%$ of primary silicate-rich melt, bearing about 3.5- -. $\mathrm{wt} \% \mathrm{H}_{2} \mathrm{O}$ and 4.7-5.6 wt $\% \mathrm{CO}_{2}$. The $\mathrm{SiO}_{2}$ content is within the range 39.2-40.4 wt $\%$, i.e. 43.1-44.1 wt $\%$ on a volatile-free basis, compatible with the 43-48 wt $\%$ estimations of near-primary average $\mathrm{SiO}_{2}$ contents of OIBs reported for the Society islands by Dasgupta et al. (2010) (Fig. 10). Good agreement is also observed for other major elements, such as $\mathrm{Al}_{2} \mathrm{O}_{3}, \mathrm{FeO}, \mathrm{MgO}, \mathrm{CaO}$ and alkalis (Fig. 10).

Simulated electrical conductivities are also in very good agreement (Fig. 10), being 10${ }^{0.59}-10^{-0.48} \mathrm{~S} \mathrm{~m}^{-1}$ compared to the $10^{-0.50}-10^{-0.29} \mathrm{~S} \mathrm{~m}^{-1}$ measured between 110 and $130 \mathrm{~km}$ depth (Tada et al., 2016). Hence, this case study demonstrates the robustness of MAGLAB in reproducing both petrological and geophysical data in a partially molten mantle column/volume. The presence of 1.2-1.5 wt $\%$ of volatile-bearing silicate melts beneath the Society hotspot as inferred by MAGLAB raises the question about mobility relative to host mantle rocks. According to Gaillard et al. (2019), such melts should percolate at $10-14 \mathrm{~cm} \mathrm{yr}^{-}$ ${ }^{1}$, whereas mantle plume ascent is estimated at $\sim 20-40 \mathrm{~cm} \mathrm{yr}^{-1}$ on the basis of geodynamic 
simulations (Arnould et al., 2020). Melt ascent via convection thus appears to dominate over melt percolation in this oceanic mantle 'hotspot' setting. 


\subsection{Heterogeneous distribution of volatile-bearing melts in the oceanic upper mantle}

Figure 11 reports electrical conductivity profiles derived from magnetotelluric surveys on various locations in the Pacific and Atlantic, from very young $(<5 \mathrm{Ma})$ to relatively old (130 Ma) seafloors. These profiles illustrate the heterogeneous electrical signature of the oceanic upper mantle, spanning the range of $10^{-3}-10^{-0.3} \mathrm{~S} \mathrm{~m}^{-1}$, and which must then be connected to the heterogeneities in temperature or volatile content in Earth's upper mantle. Figure 11 also reports the range of electrical conductivities for partially molten mantle peridotite calculated by MAGLAB from: (i) old and cold mantle (130 Ma geotherm of G13R1300 model with $T_{P}=1300^{\circ} \mathrm{C}$ from Grose and Afonso (2013)) that is highly depleted in volatiles (20 wt ppm $\mathrm{CO}_{2}$ and 50 wt ppm $\mathrm{H}_{2} \mathrm{O}$; Dasgupta and Hirschmann, 2010; Shimizu et al., 2019) to (ii) young and hot mantle (0 Ma geotherm of G13R1450 model with $T_{P}=1450^{\circ} \mathrm{C}$ from Grose and Afonso (2013)) that is highly enriched in volatiles (700 wt $\mathrm{ppm} \mathrm{CO}_{2}$ and 720 wt ppm $\mathrm{H}_{2} \mathrm{O}$; Aubaud et al., 2005).

MAGLAB simulations cover the range of mantle co duc vities observed beneath the seafloors of various ages well. The high electrical condur. . $^{+t_{1}} \mathrm{t}_{\mathrm{s}}$ of $>10^{-1} \mathrm{~S} \mathrm{~m}^{-1}$ reported at mantle depths of $<130 \mathrm{~km}$ beneath the outer rise of $\mathrm{Co}^{\prime}$ os plate seafloor (see profile "SERPENT" in Fig. 11; Naif et al., 2013; Naif, 20ı ?), the Reykjanes Ridge (see profile "RAMESSES AVR Centre" in Fig. 11; Heinson et al., 2000), or the Society hotspot (see profile "Anomaly Zone A" in Fig. 11; Tada et al., 2' 1 require melt fractions of up to 0.5-1 wt $\%$ resulting from a high degree of volatis enrichment, even when elevated $T_{P}$ are accounted for (see Sections 4 and 5.2). Very $h_{2}{ }^{{ }^{\prime}} 1 \mathrm{r}$ antle electrical conductivities $>10^{-0.5} \mathrm{~S} \mathrm{~m}^{-}$ 1 , e.g. beneath the ultraslow-spreading $\mathrm{M}^{\wedge}{ }^{\wedge}$ ns Ridge, would require even higher melt fractions of >>1 wt\% (Johansen et al., 2019). In he other hand, the lowest electrical conductivities with values of $\leq 10^{-2} \mathrm{~S} \mathrm{~m}^{-1}$ are compatible with the presence of very low melt fractions, i.e. $<<0.1 \mathrm{wt} \%$, in depleted mantle region Within the asthenosphere, at $>125 \mathrm{~km}$ depth, mantle conductivities are typically between $1 \mathrm{v}^{-2}$ and $10^{-1} \mathrm{~S} \mathrm{~m}^{-1}$ implying melt fractions of $<1 \mathrm{wt} \%$ in all cases (Fig. 11).

Combined petrological $z_{1}+1$ electrical simulations using MAGLAB confirm that the high variability of conductivity profiles in the oceanic upper mantle is related to strong heterogeneities in its volatile con 'nt (Herzberg and Asimow, 2008; Hirschmann, 2010, 2018; Ganne and Feng, 2017; In yer et al., 2017; Clerc et al., 2018). Highly variable amounts of interconnected volati's-b arin s melts, generally $<<1 \mathrm{wt} \%$, may be widespread in the uppermost convecting $n_{\text {. }}$ ntle, but their 'geophysical' detection is challenging if very small fractions are produced 'Caillard et al., 2019; Gardés et al., 2020). This could explain the rarity of a geophysically detected discontinuity near cratonic LABs (Eaton et al., 2009; Mancinelli et al., 2017). Alternatively, this reflects that the mantle at $200-250 \mathrm{~km}$ is too reducing to stabilize carbonated melt (Aulbach, 2019). MAGLAB then allows providing bounds on the volatile content for such contexts. Moreover, heterogeneities in mantle volatile content question the role of melt migration in redistributing volatiles. For instance, the very high electrical conductivities reported in the relatively ambient upper mantle beneath Mohns Ridge might be caused by large melt fractions of $>>1 \mathrm{wt} \%$, originated from melt migration and accumulation processes (Johansen et al., 2019), and shaping high bulk volatile contents ( >500 wt ppm $\mathrm{CO}_{2}-\mathrm{H}_{2} \mathrm{O}$ ). Volatile and, thus, melt migration plus redistribution can be simulated if dynamic processes including mantle convection are combined with a rigorous petrological framework for mantle melting as provided here by MAGLAB (see also Keller et al., 2016, 2017; Clerc et al., 2018). However, further development of these multi-disciplinary modeling techniques is required to continue the quest for better understanding mantle melting processes and their implications for crust-mantle evolution. 


\section{Conclusion}

MAGLAB is a new computing platform that models melt compositions, melt fractions and electrical conductivity at pressure-temperature conditions and volatile contents relevant to the upper mantle (i.e., 2-10 GPa, $900-1700^{\circ} \mathrm{C}$, depleted to enriched peridotite compositions, up to many thousands of wt ppm of $\mathrm{CO}_{2}$ and $\mathrm{H}_{2} \mathrm{O}$ ). The platform can be accessed free of charge online at http://calcul-isto.cnrs-orleans.fr/apps/maglab/. MAGLAB can be used to model melting processes in oceanic and continental intraplate settings, including kimberlite melt formation beneath cratons. Our modeling results show that erupted intraplate magma compositions correspond to the melts equilibrated near LAB depths, and that a diversity of magma types can be produced from a homogeneous peridotitic mantle source. For 'normal' upper mantle with $1350^{\circ} \mathrm{C}$ potential temperature and average - latile content of $140 \mathrm{wt} \mathrm{ppm}$ $\mathrm{CO}_{2}$ and 240 wt ppm $\mathrm{H}_{2} \mathrm{O}$, carbonatitic melt compositions $w^{\text {ith }}<i 5 \mathrm{wt} \% \mathrm{SiO}_{2}$ are produced beneath 200-250 km thick cratonic lithospheres and basanith -ba altic melt compositions with $>40$ wt $\% \mathrm{SiO}_{2}$ beneath mature ocean basins with much 'ninı ${ }^{\mathrm{r}}$ lithospheres (i.e., $60-100 \mathrm{~km}$ thick). Melts with $\mathrm{SiO}_{2}$ contents between 15-35 wt\% su: as kimberlites form only at high pressures corresponding to depths of $\geq 120 \mathrm{~km}$. Th $\mathrm{ir}$. $>$ rmation is enhanced in peridotitic mantle sources with high $\mathrm{H}_{2} \mathrm{O}$ contents in addition to $\mathrm{\Sigma}_{2}$. In a test case, our combined petrological and geophysical modeling reproduces k ow compositions of erupted melts and the measured mantle electrical conductivity fo $n$. Society hotspot. An important finding from MAGLAB simulations is that the con mu observed variability of mantle electrical conductivity can be linked to the preser.t an heterogeneous distribution of small volumes (generally $<<1 \mathrm{wt} \%$ ) of volatile-bearing $\wedge_{s}$ within Earth's upper mantle. 


\section{Acknowledgements}

We thank Mark Jellinek for manuscript handling, as well as Michel Grégoire and two anonymous reviewers for their valuable comments. We also sincerely thank Tim Holland and Eleanor Green for helpful discussions whose our modeling work has benefited, and Claude Herzberg for providing comments on a previous version of the manuscript. This work was part of the ElectroLith project and benefited from funding by the European Research Council (ERC project \#279790) and the French agency for research (ANR project \#2010 BLAN62101). GR also gratefully acknowledges funding by the French agency for research under grant Labex VOLTAIRE ANR-10-LABX-100-01. The DEEP Research Group at the University of Johannesburg is supported by the DSI-NRF CIMERA Center of Excellence, South Africa. MM was partially funded through a scholarship from the Department of Science and Technology Research Chairs Initiative as administered by the NRF South Africa (SARChI Chair grant \#64779 awarded to K.S. Viljoen), whicı we gratefully acknowledge. Additional financial support was provided to $\mathrm{ST}$ via the $\mathrm{NR}^{-\mathrm{Ir}} \mathrm{RR}$ funding framework. MM also gratefully acknowledges funding from the European $I_{\text {in }}$ is Horizon 2020 research and innovation program under the Marie Skłodowska-Curie rar. agreement No. 842339. SA gratefully acknowledges funding by the German Resear. Foundation under grant AU356/11. Readers can access data and additional information not reported in the main paper via the supporting online resources. 
Appendix A. Supplementary Information 


\section{References}

Adam, C., Yoshida, M., Isse, T., Suetsugu, D., Fukao, Y., \& Barruol, G. (2010). South Pacific hotspot swells dynamically supported by mantle flows. Geophysical Research Letters, 37, 6 pp., doi: 10.1029/2010GL042534.

An, M., Wiens, D.A., Zhao, Y., Feng, M., Nyblade, A., Kanao, M., Li, Y., Maggi, A., Lévêque, J.-J. (2015). Temperature, lithosphere-asthenosphere boundary, and heat flux beneath the Antarctic Plate inferred from seismic velocities. Journal of Geophysical Research, 120, 8720-8742, doi: 10.1002/2014JB011332.

Ariskin, A.A. (1999). Phase equilibria modeling in igneous petrology: use of COMAGMAT model for simulating fractionation of ferro-basaltic magmas and the genesis of high-alumina basalt. Journal of Volcanology and Geothermc! Research, 90, 115-162, doi: 10.1016/S0377-0273(99)00022-0.

Arnould, M., Coltice, N., Flament, N., \& Mallard, C. (2020). Plate tectonics and mantle controls on plume dynamics. Earth and Planetary sc:once Letters, 547, 15 pp., doi: 10.1016/j.epsl.2020.116439.

Aubaud, C., Pineau, F., Hékinian, R., \& Javoy, av: (2005). Degassing of $\mathrm{CO}_{2}$ and $\mathrm{H}_{2} \mathrm{O}$ in submarine lavas from the Society hotspot. Earth ard I lanetary Science Letters, 235, 511527, doi: 10.1016/j.epsl.2005.04.047.

Aulbach, S. (2019). Cratonic Lithosphe: ' Jiscontinuities: Dynamics of Small-Volume Melting, Metacratonization, and a Possi' '- 'ole for Brines: Chapter 10 in Lithospheric Discontinuities. Edited by Huai,"l Yuan and Barbara Romanowicz, doi: 10.1002/9781119249740.ch10.

Aulbach, S., \& Arndt, N. T (¿19) Eclogites as Palaeodynamic Archives: Evidence for Warm (not hot) and Deplete! ( i ut heterogeneous and evolving) Archaean Ambient Mantle. Earth and Planetary Scie «. Lutters, 505, 162-172, doi: 10.1016/j.epsl.2018.10.025.

Aulbach, S., Massuyeru, i1., \& Gaillard, F. (2017). Origins of cratonic mantle discontinuities: A view from ne. ology, geochemistry and thermodynamic models. Lithos, 268-271, 364-382, doi: 10. ' '16'j.lithos.2016.11.004.

Baba, K., Chav A.D., Evans, R.L., Hirth, G., \& Mackie, R.L. (2006). Mantle dynamics beneath the $\mathrm{Ea}^{+}+\mathrm{Pacific}$ Rise at $17^{\circ} \mathrm{S}$ : Insights from the Mantle Electromagnetic and Tomography (MELT) _..periment. Journal of Geophysical Research, 111, 18 pp., doi: 10.1029/2004JB003598.

Baba, K., Chen, J., Sommer, M., Utada, H., Geissler, W.H., Jokat, W., \& Jegen, M. (2017a). Marine magnetotellurics imaged no distinct plume beneath the Tristan da Cunha hotspot in the southern Atlantic Ocean. Tectonophysics, 716, 52-63, doi: 10.1016/j.tecto.2016.09.033.

Baba, K., Tada, N., Matsuno, T., Liang, P., Li, R., Zhang, L., Shimizu, H., Abe, N., Hirano, N., Ichiki, M., \& Utada, H. (2017b). Electrical conductivity of old oceanic mantle in the northwestern Pacific I: 1-D profiles suggesting differences in thermal structure not predictable from a plate cooling model. Earth, Planets and Space, 69, 23 pp., doi: 10.1186/s40623-017-0697-0.

Baba, K., Tada, N., Zhang, L., Liang, P., Shimizu, H., \& Utada, H. (2013). Is the electrical conductivity of the northwestern Pacific upper mantle normal? Geochemistry, Geophysics, Geosystems, 14, 4969-4979, doi: 10.1002/2013GC004997. 
Baba, K., Utada, H., Goto, T.-N., Kasaya, T., Shimizu, H., \& Tada, N. (2010). Electrical conductivity imaging of the Philippine Sea upper mantle using seafloor magnetotelluric data. Physics of the Earth and Planetary Interiors, 183, 44-62, doi: 10.1016/j.pepi.2010.09.010.

Ballmer, M.D., Ito, G., van Hunen, J., \& Tackley, P.J. (2011). Spatial and temporal variability in Hawaiian hotspot volcanism induced by small-scale convection. Nature Geoscience, 4, 457-460, doi: 10.1038/NGEO1187.

Baudouin, C., \& Parat, F. (2020). Phlogopite-Olivine Nephelinites Erupted During Early Stage Rifting, North Tanzanian Divergence. Frontiers in Earth Science, 8, 22 pp., doi: 10.3389/feart.2020.00277.

Baudouin, C., Parat, F., Denis, C.M.M., \& Mangasini, F. (2016). Contributions to Mineralogy and Petrology, 171, 20 pp., doi: 10.1007/s00410-016-1273-5.

Becker, M., \& le Roex, A.P. (2006). Geochemistry of South African On- and Offcraton, Group I and Group II Kimberlites: Petrogenesis and ` our e Region Evolution. Journal of Petrology, 47, 673-703, doi: 10.1093/petrology/egi089.

Bodinier, J.-L., Vasseur, G., Vernieres, J., Jư ’’, C., \& Fabries, J. (1990). Mechanisms of Mantle Metasomatism: Geochemical b. ilence from the Lherz Orogenic Peridotite. Journal of Petrology, 31, 597-628, doi: 1C 109 i/petrology/31.3.597.

Brey, G.P., Bulatov, V.K., \& Girnis, A.V (2009). Influence of water and fluorine on melting of carbonated peridotite at 6 and $1($ GPa. Lithos, 112S, 249-259, doi: 10.1016/j.lithos.2009.04.037.

Carmichael, I.S.E., Nicholls, J., Sm.h, A.L. (1970). Silica activity in igneous rocks. American Mineralogist, 55, 246-263. doi: 1i 1007/BF00373791.

Chantel, J., Manthilake, G., A na `ult, D., Novella, D., Yu, T., \& Wang, Y. (2016). Experimental evidence supports nnt partial melting in the asthenosphere. Science

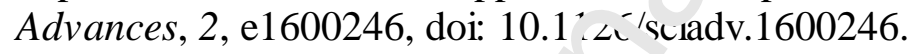

Clerc, F., Behn, M.D. Paınentier, E.M., \& Hirth, G. (2018). Predicting Rates and Distribution of Carbonate $v^{*}$ oltug in Oceanic Upper Mantle: Implications for Seismic Structure and Global Carbın 'ycling. Geophysical Research Letters, 45, 6944-6953, doi: 10.1029/2018GL078142.

Connolly, J.A.D. '2005). Computation of phase equilibria by linear programming: A tool for geodynamic mi e eling and its application to subduction zone decarbonation. Earth and Planetary Science Letters, 236, 524-541, doi: 10.1016/j.epsl.2005.04.033.

Dasgupta, R. (2018). Volatile-bearing partial melts beneath oceans and continentswhere, how much, and of what compositions? American Journal of Science, 318, 141-165, doi: $10.2475 / 01.2018 .06$.

Dasgupta, R., \& Hirschmann, M.M. (2006). Melting in the Earth's deep upper mantle caused by carbon dioxide. Nature, 440, 659-662, doi: 10.1038/nature04612.

Dasgupta, R., \& Hirschmann, M.M. (2010). The deep carbon cycle and melting in Earth's interior. Earth and Planetary Science Letters, 298, 1-13, doi: 10.1016/j.epsl.2010.06.039.

Dasgupta, R., Jackson, M.G., \& Lee, C.-T. A. (2010). Major element chemistry of ocean island basalts - Conditions of mantle melting and heterogeneity of mantle source. Earth and Planetary Science Letters, 289, 377-392, doi: 10.1016/j.epsl.2009.11.027. 
Dasgupta, R., Hirschmann, M.M., \& Smith, N.D. (2007). Water follows carbon: $\mathrm{CO}_{2}$ incites deep silicate melting and dehydration beneath mid-ocean ridges. Geology, 35, 135-138, doi: 10.1130/G22856A.1.

Dasgupta, R., Mallik, A., Tsuno, K., Withers, A.C., Hirth, G., \& Hirschmann, M.M. (2013). Carbon-dioxide-rich silicate melt in the Earth's upper mantle. Nature, 493, 211-215, doi: 10.1038/nature11731.

Davies, G.F. (2009). Effect of plate bending on the Urey ratio and the thermal evolution of the mantle. Earth and Planetary Science Letters, 287, 513-518, doi: 10.1016/j.epsl.2009.08.038.

Davies, D.R., Rawlinson, N., Iaffaldano, G., \& Campbell, I.H. (2015). Lithospheric controls on magma composition along Earth's longest continental hotspot track. Nature, 525, 511-514, doi: 10.1038/nature14903.

DeCapitani, C., \& Kirschen, M. (1998). A generai ${ }^{\circ e d}$ multicomponent excess function with application to immiscible liquids in the system ( aU $\mathrm{SiO} 2-\mathrm{TiO} 2$. Geochimica et

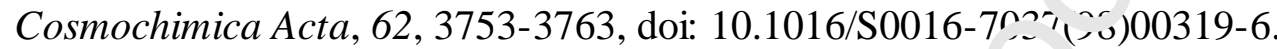

Doucelance, R., Hammouda, T., Moreira, M., iz '^stins, J.C. (2010). Geochemical constraints on depth of origin of oceanic carbonatites. The Cape Verde case. Geochimica et Cosmochimica Acta, 74, 7261-7282, doi: 10.1016/j.ร ๆ.2( 10.09.024.

Eaton, D.W., Darbyshire, F., Evans, R.L., Frutter, H., Jones, A.G., \& Yuan, X. (2009). The elusive lithosphere-asthenosphere boundary $\left(_{L t} \mathrm{~B}\right)$ beneath cratons. Lithos, 109, 1-22, doi: 10.1016/j.lithos.2008.05.009.

Eggler, D.H., 1976. Does $\mathrm{CO}_{2}$ ar se partial melting in the low-velocity layer of the mantle? Geology, 4, 69-72, doi: https://doi.org/10.1130/00917613(1976)4<69:DCCPMI>2.0.CO;2.

Eguchi, J., \& Dasgupta, R. $2 \mathrm{Ju}^{\mathrm{j}}$ ). Redox state of the convective mantle from $\mathrm{CO}_{2}$ trace element systematics of ocear $1 \mathrm{c}$ hasalts. Geochemical Perspectives Letters, 8, 17-21, doi: 10.7185/geochemlet.1823.

Ellam, R.M. (1992). ' itıospheric thickness as a control on basalt geochemistry. Geology, 20, 153-156, doi: ㄱา1 30/0091-7613(1992)020<0153:LTAACO>2.3.CO;2.

Evans, R.L., Yir'? ( s., Baba, K., Forsyth, D., Chave, A., \& Mackie, R. (2005). Geophysical evidence the $\mathrm{n}$ the MELT area for compositional controls on oceanic plates. Nature, 437, 249-252, $\therefore \therefore$ : 10.1038/nature04014.

Fischer, K.M., Ford, H.A., Abt, D.L., \& Rychert, C.A. (2010). The LithosphereAsthenosphere Boundary. Annual Review of Earth and Planetary Sciences, 38, 551-575, doi: 10.1146/annurev-earth-040809-152438.

Foley, S.F. (2008). Rejuvenation and erosion of the cratonic lithosphere. Nature Geoscience, 1, 503-510, doi: 10.1038/ngeo261.

Foley, S.F., Yaxley, G.M., Rosenthal, A., Buhre, S., Kiseeva, E.S., Rapp, R.P., \& Jacob, D.E. (2009). The composition of near-solidus melts of peridotite in the presence of $\mathrm{CO}_{2}$ and $\mathrm{H}_{2} \mathrm{O}$ between 40 and 60 kbar. Lithos, 112S, 274-283, doi: 10.1016/j.lithos.2009.03.020.

French, S.W., \& Romanowicz, B. (2015). Broad plumes rooted at the base of the Earth's mantle beneath major hotspots. Nature, 525, 95-99, doi: 10.1038/nature14876. 
Gaillard, F., Malki, M., Iacono-Marziano, G., Pichavant, M., \& Scaillet, B. (2008). Carbonatite Melts and Electrical Conductivity in the Asthenosphere. Science, 322, 1363-1365, 1126/science. 1164446.

Gaillard, F., Scaillet, B., Pichavant, M., \& Iacono-Marziano, G. (2015). The redox geodynamics linking basalts and their mantle sources through space and time. Chemical Geology, 418, 217-233, doi: 10.1016/j.chemgeo.2015.07.030.

Gaillard, F., Sator, N., Gardés, E., Guillot, B., Massuyeau, M., Sifré, D., Hammouda, T., \& Richard, G. (2019). The Link between the Physical and Chemical Properties of CarbonBearing Melts and Their Application for Geophysical Imaging of Earth's Mantle. In B. Orcutt, I. Daniel, \& R. Dasgupta (Eds.), Deep Carbon: Past to Present (pp. 163-187). Cambridge: Cambridge University Press.

Ganne, J., \& Feng, X. (2017). Primary magmas and mantle temperatures through time. Geochemistry, Geophysics, Geosystems, 18, 872-888, doi: 10.1`9/2019GC008227.

Gardés, E., Gaillard, F., \& Tarits, P. (2014). Tr waı 1 a unified hydrous olivine electrical conductivity law. Geochemistry, Geophysics, Fnostems, 15, 4984-5000, doi: 10.1002/2014GC005496.

Gardés, E., Laumonier, M., Massuyeau, M., \& G villard, F. (2020). Unravelling partial melt distribution in the oceanic low velocity zone. Ea. ${ }^{t h}$ c nd Planetary Science Letters, 540, 116242, doi: 10.1016/j.epsl.2020.116242.

Ghiorso, M.S., \& Sack, R.O. (1995). Ther iical mass transfer in magmatic processes IV. A revised and internally consistent th rmodynamic model for the interpolation and extrapolation of liquid-solid equilibria $i_{1} \mathrm{r}$ agnıdic systems at elevated temperatures and pressures. Contributions to Minera.' 'gy and Petrology, 119, 197-212, doi: 10.1007/BF00307281.

Ghiorso, M.S., Hirschmann J I M.1., Reiners, P.W., \& Kress, V.C. (2002). The pMELTS: A revision of MELT ${ }^{c}$ f $r$ improved calculation of phase relations and major element partitioning related to nartul melting of the mantle to $3 \mathrm{GPa}$. Geochemistry, Geophysics, Geosystems, 3, 36 , p., ùoi: 10.1029/2001GC000217.

Ghiorso, M.S., \& Cuala., G.A.R. (2015). An $\mathrm{H}_{2} \mathrm{O}-\mathrm{CO}_{2}$ mixed fluid saturation model compatible with rhyolit, - ELTS. Contributions to Mineralogy and Petrology, 169, doi: $10.1007 / \mathrm{s} 00410-0,5-, 14,-8$.

Ghosh, S., Litasnv, K., \& Ohtani, E. (2014). Phase relations and melting of carbonated peridotite between 10 and $20 \mathrm{GPa}$ : a proxy for alkali- and $\mathrm{CO}_{2}$-rich silicate melts in the deep mantle. Contributions to Mineralogy and Petrology, 167, 23 pp., doi: 10.1007/s00410-0140964-Z

Giuliani, A., \& Pearson, D.G. (2019). Kimberlites: From Deep Earth to Diamond Mines. Elements, 15, 377-380, doi: 10.2138/gselements.15.6.377.

Grégoire, M., Bell, D.R., \& le Roex, A.P. (2003). Garnet Lherzolites from the Kaapvaal Craton (South Africa): Trace Element Evidence for a Metasomatic History. Journal of Petrology, 44, 629-657, doi: 10.1093/petrology/44.4.629.

Grose, C.J., \& Afonso, J.-C. (2013). Comprehensive plate models for the thermal evolution of oceanic lithosphere. Geochemistry, Geophysics, Geosystems, 14, 3751-3778, doi: 10.1002/ggge.20232. 
Grose, C.J., \& Afonso, J.-C. (2019). Chemical Disequilibria, Lithospheric Thickness, and the Source of Ocean Island Basalts. Journal of Petrology, 60, 755-790, doi: 10.1093/petrology/egz012.

Gualda, G.A.R., Ghiorso, M.S., Lemons, R.V., \& Carley, T.L. (2012). RhyoliteMELTS: a Modified Calibration of MELTS Optimized for Silica-rich, Fluid-bearing Magmatic Systems. Journal of Petrology, 53, 875-890, doi: 10.1093/petrology/egr080.

Gudfinnsson, G.H., \& Presnall, D.C. (2005). Continuous Gradations among Primary Carbonatitic, Kimberlitic, Melilititic, Basaltic, Picritic, and Komatiitic Melts in Equilibrium with Garnet Lherzolite at 3-8 GPa. Journal of Petrology, 46, 1645-1659, doi: 10.1093/petrology/e gi029.

Guo, P., Niu, Y., Sun, P., Gong, H., \& Wang, X. (2020). Lithosphere thickness controls continental basalt compositions: An illustration using Cenozoic basalts from eastern China. Geology, 48, 128-133, doi: 10.1130/G46710.1.

Haase, K.M. (1996). The relationship between the age of the lithosphere and the composition of oceanic magmas: Constraints on partial meing, mantle sources and the thermal structure of the plates. Earth and Planetary Scie ice Letters, 144, 75-92, doi: 10.1016/0012-821X(96)00145-8.

Hammouda, T., \& Keshav, S. (2015). Meltir ${ }_{2}$ in he mantle in the presence of carbon: Review of experiments and discussion on the origin of urbonatites. Chemical Geology, 418, 171-188, doi: 10.1016/j.chemgeo.2015.05.018.

Hauri, E., Cottrell, E., Kelley, K., Tu. ker, J., Shimizu, K., Voyer, M., Marske, J., \& Saal, A. (2019). Carbon in the Conver .ng Mautle. In B. Orcutt, I. Daniel, \& R. Dasgupta (Eds.), Deep Carbon: Past to Present (, n. 237-275). Cambridge: Cambridge University Press.

Heinson, G., Constable, S., \& White, A. (2000). Episodic Melt Transport at MidOcean Ridges Inferred from Mamet 't lluric Sounding. Geophysical Research Letters, 27, 2317-2320, doi: 10.1029/2000GL 111473.

Herzberg, C., \& Asimu v, P.D. (2008). Petrology of some oceanic island basalts: PRIMELT2.XLS software for primary magma calculation. Geochemistry, Geophysics, Geosystems, 9, 25 pp., dr: : (\%.1029/2008GC002057.

Hirano, N., Tan.havill, E., Yamamoto, J., Abe, N., Ingle, S.P., Kaneoka, I., Hirata, T., Kimura, J.-I., Ishii, T. Jgawa, Y., Machida, S., \& Suyehiro, K. (2006). Volcanism in Response to Plate Flexure. Science, 313, 1426-1428, doi: 10.1126/science.1128235.

Hirschmann, M.M. (2000). Mantle solidus: Experimental constraints and the effects of peridotite composition. Geochemistry, Geophysics, Geosystems, 1, 26 pp., doi: 10.1029/2000GC000070.

Hirschmann, M.M. (2010). Partial melt in the oceanic low velocity zone. Physics of the Earth and Planetary Interiors, 179, 60-71, doi: 10.1016/j.pepi.2009.12.003.

Hirschmann, M.M. (2018). Comparative deep Earth volatile cycles: The case for C recycling from exosphere/mantle fractionation of major $\left(\mathrm{H}_{2} \mathrm{O}, \mathrm{C}, \mathrm{N}\right)$ volatiles and from $\mathrm{H}_{2} \mathrm{O} / \mathrm{Ce}, \mathrm{CO}_{2} / \mathrm{Ba}$, and $\mathrm{CO}_{2} / \mathrm{Nb}$ exosphere ratios. Earth and Planetary Science Letters, 502, 262-273, doi: 10.1016/j.epsl.2018.08.023.

Hirschmann, M.M., Kogiso, T., Baker, M.B., \& Stolper, E.M. (2003). Alkalic magmas generated by partial melting of garnet pyroxenite. Geology, 31, 481-484, doi: 10.1130/00917613(2003)031<0481:AMGBPM>2.0.CO;2. 
Hirschmann, M.M., Tenner, T., Aubaud, C., \& Withers, A.C. (2009). Dehydration melting of nominally anhydrous mantle: The primacy of partitioning. Physics of the Earth and Planetary Interiors, 176, 54-68, doi: 10.1016/j.pepi.2009.04.001.

Holland, T.J.B., \& Powell, R. (2011). An improved and extended internally consistent thermodynamic dataset for phases of petrological interest, involving a new equation of state for solids. Journal of Metamorphic Geology, 29, 333-383, doi: 10.1111/j.15251314.2010.00923.x.

Holtzmann, B. (2016). Questions on the existence, persistence and mechanical effects of a very small melt fraction in the asthenosphere. Geochemistry, Geophysics, Geosystems, 17, 470-484, doi:10.1002/2015GC006102.

Humphreys, E.R., \& Niu, Y. (2009). On the composition of ocean island basalts (OIB): The effects of lithospheric thickness variation and mantle metasomatism. Lithos, 112, 118-136, doi: 10.1016/j.lithos.2009.04.038.

Jaupart, C, \& Mareschal, J.C. (1999). The ther nal structure and thickness of continental roots. Lithos, 48, 93-114, doi: 10.1016/S0024-4ヘ2パ゙)00023-7.

Johansen, S.E., Panzner, M., Mittet, R., Amunds sn, U.E.F., Lim, A., Vik, E., Landrø, M., \& Arntsen, B. (2019). Deep electrical imaging of th- ultraslow-spreading Mohns Ridge. Nature, 567, 379-383, doi: 10.1038/s41586-019-101C.0.

Katsura, T., Baba, K., Yoshino, T., \& Knoi,o, 1. (2017). Electrical conductivity of the oceanic asthenosphere and its interpretat $r$ based on laboratory measurements. Tectonophysics, 717, 162-181, doi: 10.1016/1... cto. 2017.07 .001 .

Kawakatsu, H., \& Utada, H. (2 J17). Seismic and Electrical Signatures of the Lithosphere-Asthenosphere System of the N.rmal Oceanic Mantle. Annual Review of Earth and Planetary Sciences, 45, 139-167, a $\cdot$ - 10.1146/annurev-earth-063016-020319.

Kawakatsu, H., Kumar, P., Taku, Y., Shinohara, M., Kanazawa, T., Araki, E., \& Suyehiro, K. (2009). Seismic Erki nce for Sharp Lithosphere-Asthenosphere Boundaries of Oceanic Plates. Science, 324, 4ny. 502, doi: 10.1126/science.1169499.

Key, K., Constable, i Liu, L., \& Pommier, A. (2013). Electrical image of passive mantle upwelling beneath the northern East Pacific Rise. Nature, 495, 499-502, doi: 10.1038/nature11932.

Keller, T., \& Ka.7, R.F. (2016). The Role of Volatiles in Reactive Melt Transport in the Asthenosphere. Jou, al of Petrology, 57, 1073-1108, doi: 10.1093/petrology/egw030.

Keller, T., Katz, R.F., \& Hirschmann, M.M. (2017). Volatiles beneath mid-ocean ridges: Deep melting, channelised transport, focusing, and metasomatism. Earth and Planetary Science Letters, 464, 55-68, doi: 10.1016/j.eps1.2017.02.006.

Klein-BenDavid, O., Izraeli, E.S., Hauri, E., \& Navon, O. (2007). Fluid inclusions in diamonds from the Diavik mine, Canada and the evolution of diamond-forming fluids. Geochimica et Cosmochimica Acta, 71, 723-744, doi: 10.1016/j.gca.2006.10.008.

Korenaga, J. (2008). Urey ratio and the structure and evolution of Earth's mantle. Reviews of Geophysics, 46, 32 pp., doi: 10.1029/2007RG000241.

le Roex, A.P. (1986). Geochemical correlation between southern African kimberlites and South Atlantic hotspots. Nature, 324, 243-245, doi: 10.1038/324243a0.

Lee, C.-T. A. (2003). Compositional variation of density and seismic velocities in natural peridotites at STP conditions: Implications for seismic imaging of compositional 
heterogeneities in the upper mantle. Journal of Geophysical Research, 108, 20 pp., doi: 10.1029/2003JB002413.

Le Voyer, M., Kelley, K.A., Cottrell, E., Hauri, E.H. (2017). Heterogeneity in mantle carbon content from $\mathrm{CO}_{2}$-undersaturated basalts. Nature Communications, 8, 8 pp., doi: 10.1038/ncomms 14062 .

Liu, J., Cai, R., Pearson, G., \& Scott, J.M. (2019). Thinning and destruction of the lithospheric mantle root beneath the North China Craton: A review. Earth-Science Reviews, 196, 18 pp., doi: 10.1016/j.earscirev.2019.05.017.

Lizarralde, D., Chave, A., Hirth, G., \& Schultz, A. (1995). Northeastern Pacific mantle conductivity profile from long-period magnetotelluric sounding using Hawaii-to-California submarine cable data. Journal of Geophysical Research, 100, 17837-17854, doi: 10.1029/95JB01244.

Lu, J., Tilhac, R., Griffin, W.L., Zheng, J., Xiong, Q., v'veira, B., \& O’Reilly, S.Y. (2020). Lithospheric memory of subduction in mantle pyrc xen e xenoliths from rift-related basalts. Earth and Planetary Science Letters, 544, 14 pp., d $\therefore$ _ ₹.1016/j.epsl.2020.116365.

Machida, S., Kogiso, T., \& Hirano, N. (2017)

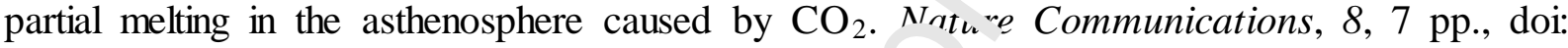
$10.1038 /$ ncomms 14302 .

Mancinelli, N.J., Fischer, K.M., \& Dalton C.A. (2017). How Sharp Is the Cratonic Lithosphere-Asthenosphere Transition? Geophysi r ${ }^{2}$ ?esearch Letters, 44, 10189-10197, doi: 10.1002/2017GL074518.

Marty, B. (2012). The origins $\mathrm{ai}^{-1} \mathrm{~s}$ sncentrations of water, carbon, nitrogen and noble gases on Earth. Earth and Planeta.y Science Letters, 313-314, 56-66, doi: 10.1016/j.epsl.2011.10.040.

Massuyeau, M., Gardés, E. M rizet, Y., \& Gaillard, F. (2015). A model for the activity of silica along the $\ddot{a}_{1}$ honatite-kimberlite-mellilitite-basanite melt compositional joint. Chemical Geology, 418, 2厅 216, doi: 10.1016/j.chemgeo.2015.07.025.

Mather, K.A., Pearson, D.G., McKenzie, D., Kjarsgaard, B.A., \& Priestley, K. (2011). Constraints on the depth an ${ }^{\prime}$ thermal history of cratonic lithosphere from peridotite xenoliths, xenocrysts and seismolo $\varepsilon$ y. L ithos, 125, 729-742, doi: 10.1016/j.lithos.2011.04.003.

Matsuno, T., Seå a, N., Evans, R.L., Chave, A.D., Baba, K., White, A., Goto, T.-N., Heinson, G., Boren, G., Ioneda, A., \& Utada, H. (2010). Upper mantle electrical resistivity structure beneath the central Mariana subduction system. Geochemistry, Geophysics, Geosystems, 11, 24 pp., doi: 10.1029/2010GC003101.

McKenzie, D., \& Bickle, M.J. (1988). The Volume and Composition of Melt Generated by Extension of the Lithosphere. Journal of Petrology, 29, 625-679, doi: 10.1093/petrology/29.3.625.

McKenzie, D., Jackson, J., \& Priestley, K. (2005). Thermal structure of oceanic and continental lithosphere. Earth and Planetary Science Letters, 233, 337-349, doi: 10.1016/j.epsl.2005.02.005.

Moussallam, Y., Longpré, M.-A., McCammon, C., Gomez-Ulla, A., Rose-Koga, E.F., Scaillet, B., Peters, N., Gennaro, E., Paris, R., \& Oppenheimer, C. (2019). Mantle plumes are oxidised. Earth and Planetary Science Letters, 527, 10 pp., doi: 10.1016/j.epsl.2019.115798. 
Moussallam, Y., Morizet, Y., \& Gaillard, F. (2016). $\mathrm{H}_{2} \mathrm{O}-\mathrm{CO}_{2}$ solubility in low $\mathrm{SiO}_{2}-$ melts and the unique mode of kimberlite degassing and emplacement. Earth and Planetary Science Letters, 447, 151-160, doi: 10.1016/j.epsl.2016.04.037.

Müller, R.D., Sdrolias, M., Gaina, C., \& Roest, W.R. (2008). Age, spreading rates, and spreading asymmetry of the world's ocean crust. Geochemistry, Geophysics, Geosystems, 9, 19 pp., doi: 10.1029/2007GC001743.

Naif, S. (2018). An upper bound on the electrical conductivity of hydrated oceanic mantle at the onset of dehydration melting. Earth and Planetary Science Letters, 482, 357366, doi: 10.1016/j.eps1.2017.11.024.

Naif, S., Key, K., Constable, S., \& Evans R.L. (2013). Melt-rich channel observed at the lithosphere-asthenosphere boundary. Nature, 495, 356-359, doi: 10.1038/nature11939.

Neal, C.R., \& Davidson, J.P. (1989). An unmetasomatized source for the Malaitan alnöite (Solomon Islands): petrogenesis involving zone refining, megacryst fractionation, and assimilation of oceanic lithosphere. Geochimica et Cosmochi nic Acta, 53, 1975-1990, doi: 10.1016/0016-7037(89)90318-9.

Ni, H., Keppler, H. \& Behrens, H. (2011). Ele ttis conductivity of hydrous basaltic melts: implications for partial melting in the upper mantle. Contributions to Mineralogy and Petrology, 162, 637-650, doi: 10.1007/s00410-011-C 17- 4 .

Niu, Y., \& Green, D.H. (2018). The petrowgical control on the lithosphereasthenosphere boundary (LAB) beneath ocean L a , In. Earth-Science Reviews, 185, 301-307, doi: 10.1016/j.earscirev.2018.06.011.

Niu, Y., Wilson, M., Humphrey. F.R., \& O'Hara, M. (2011). The Origin of Intraplate Ocean Island Basalts (OIB): the Lid L $\mathcal{C}^{\top}$ ect and its Geodynamic Implications. Journal of Petrology, 52, 1443-1468, doi: 10.109s'netrology/egr030.

Nolasco, R., Tarits, P., Fillc yy, .H., \& Chave, A.D. (1998). Magnetotelluric imaging of the Society Islands hotspot. .ounul of Geophysical Research, 103, 30287-30309, doi: 10.1029/98JB02129.

Novella, D., Frost, D.J., Hauri, E.H., Bureau, H., Raepsaet, C., \& Roberge, M. (2014). The distribution of $\mathrm{H}_{2} \mathrm{O}$ bu ${ }^{+} w f$ en silicate melt and nominally anhydrous peridotite and the onset of hydrous melting in th : deep upper mantle. Earth and Planetary Science Letters, 400, 1-13, doi: 10.1016/j.eps.' ?vi+.05.006.

O'Reilly, S.Y., ^ $\sim$ Griffin, W.L. (2010). The continental lithosphere-asthenosphere boundary: Can we sample it? Lithos, 120, 1-13, doi: 10.1016/j.lithos.2010.03.016.

Parsons, B., \& McKenzie, D. (1978). Mantle Convection and the Thermal Structure of the Plates. Journal of Geophysical Research, 83, 4485-4496, doi: 10.1029/JB083iB09p04485.

Pilet, S., Baker, M.B., \& Stolper, E.M. (2008). Metasomatized Lithosphere and the Origin of Alkaline Lavas. Science, 320, 916-919, doi: 10.1126/science.1156563.

Pilet, S., Abe, N., Rochat, L., Kaczmarek, M.-A., Hirano, N., Machida, S., Buchs, D.M., Baumgartner, P.O., \& Müntener, O. (2016). Pre-subduction metasomatic enrichment of the oceanic lithosphere induced by plate flexure. Nature Geoscience, 9, 898-903, doi: 10.1038/ngeo2825.

Priestley, K., McKenzie, D., \& Ho, T. (2019). A Lithosphere-Asthenosphere Boundary-a Global Model Derived from Multimode Surface-Wave Tomography and 
Petrology. In Lithospheric Discontinuities (Eds., H. Yuan and B. Romanowicz). doi:10.1002/9781119249740.ch6.

Prytulak, J., \& Elliott, T. (2007). $\mathrm{TiO}_{2}$ enrichment in ocean island basalts. Earth and Planetary Science Letters, 263, 388-403, doi: 10.1016/j.epsl.2007.09.015.

Ringwood, A.E., Kesson, S.E., Hibberson, W., \& Ware, N. (1992). Origin of kimberlites and related magmas. Earth and Planetary Science Letters, 113, 521-538, doi: $10.1016 / 0012-821 \mathrm{X}(92) 90129-\mathrm{J}$.

Rohrbach, A., \& Schmidt, M.W. (2011). Redox freezing and melting in the Earth's deep mantle resulting from carbon-iron redox coupling. Nature, 472, 209-212, doi: 10.1038/nature09899.

Rychert, C.A., Harmon, N., \& Tharimena, S. (2020). Seismic Imaging of the Base of the Ocean Plates. In Lithospheric Discontinuities (Eds., H. 'uan and B. Romanowicz), doi: 10.1002/9781119249740.ch4.

Sarafian, E., Evans, R.L., Collins, J.A., Elsenbeck, \& C xetani, G.A., Gaherty, J.B., Hirth, G., \& Lizzarralde, D. (2015). The electrical structur oi the central Pacific upper mantle constrained by the NoMelt experiment. Geochemistry, Gu nysics, Geosystems, 16, $1115-$ 1132, doi: 10.1002/2014GC005709.

Sato, Y., Hirano, N., Machida, S., Yamamote I., Nakanishi, M., Ishii, T., Taki, A., Yasukawa, K., \& Kato, Y. (2018). Direct ascent tc the surface of asthenospheric magma in a region of convex lithospheric flexure. Internatı ai Geology Review, 60, 1231-1243, doi: 10.1080/00206814.2017.1379912.

Schmeling, H. (1986). Numeric ' $r$.odels on the influence of partial melt on elastic, anelastic and electrical properties of rocks. I - rt II electrical conductivity. Earth and Planetary Science Letters, 43, 123-136, doi: 10.1七6/0031-9201(86)90080-4.

Schmerr, N. (2012). The ( utenberg Discontinuity: Melt at the LithosphereAsthenosphere Boundary. Science, ¿ $84,1480-1483$, doi: 10.1126/science.1215433.

Schmidt, M.W., \& P.li, 2. (2014). 4.19 - Devolatilization During Subduction. In Treatise on Geochemistry, St:nrul Edition (Eds., Heinrich D. Holland and Karl K. Turekian), 669-701, doi: 10.1016/B978- ר-03-095975-7.00321-1.

Selway, K., O'L ınn ll, J.P., \& Özaydin, S. (2019). Upper Mantle Melt Distribution From Petrologically Con trained Magnetotellurics. Geochemistry, Geophysics, Geosystems, 20, 3328-3346, doi: 10. $\cong 29 / 2019$ GC008227.

Selway, K., \& O'Donnell, J.P. (2019). A small, unextractable melt fraction as the cause for the low velocity zone. Earth and Planetary Science Letters, 517, 117-124, doi: 10.1016/j.epsl.2019.04.012.

Shimizu, K., Ito, M., Chang, Q., Miyazaki, T., Ueki, K., Toyama, C., Senda, R., Vaglarov, B.S., Ishikawa, T., \& Kimura J.-I. (2019). Identifying volatile mantle trend with the water-fluorine-cerium systematics of basaltic glass. Chemical Geology, 522, 283-294, doi: 10.1016/j.chemgeo.2019.06.014.

Sifré, D., Hashim, L., \& Gaillard, F. (2015). Effects of temperature, pressure and chemical compositions on the electrical conductivity of carbonated melts and its relationship with viscosity. Chemical Geology, 418, 189-197, doi: 10.1016/j.chemgeo.2014.09.022. 
Sifré, D., Gardés, E., Massuyeau, M., Hashim, L., Hier-Majumder, S., \& Gaillard, F. (2014). Electrical conductivity during incipient melting in the oceanic low-velocity zone. Nature, 509, 81-85, doi: 10.1038/nature13245.

Simonetti, A., \& Neal, C.R. (2010). In-situ chemical, U-Pb dating, and Hf isotope investigation of megacrystic zircons, Malaita (Solomon Islands): Evidence for multi-stage alkaline magmatic activity beneath the Ontong Java Plateau. Earth and Planetary Science Letters, 295, 251-261, doi: 10.1016/j.eps1.2010.04.004.

Smart, K.A., Tappe, S., Ishikawa, A., Pfänder, J.A., \& Stracke, A. (2019). K-rich hydrous mantle lithosphere beneath the Ontong Java Plateau: Significance for the genesis of oceanic basalts and Archean continents. Geochimica et Cosmochimica Acta, 248, 311-342.

Sobolev, A.V., Hofmann, A.W., Kuzmin, D.V., Yaxley, G.M., Arndt, N.T., Chung, S.L., Danyushevsky, L.V., Elliott, T., Frey, F.A., Garcia, M.O., Gurenko, A.A., Kamenetsky, V.S., Kerr, A.C., Krivolutskaya, N.A., Matvienkov, V.V., 1 kogosian, I.K., Rocholl, A., Sigurdsson, I.A., Sushchevskaya, N.M., \& Teklay, M. (2007) The Amount of Recycled Crust in Sources of Mantle-Derived Melts. Science, 316, 412-417, a vi: 1 J.1126/science.1138113.

Soltanmohammadi, A., Grégoire, M., Rabinowicz, M. Gerbault, M., Ceuleneer, G., Rahgoshay, M., Bystricky, M., \& Benoit, M. (2018). T. nsport of Volatile-rich Melt from the Mantle Transition Zone via Compaction Pockets: In plic ctions for Mantle Metasomatism and the Origin of Alkaline Lavas in the Turkish-Iranian Pla au. Journal of Petrology, 59, 22732310, doi: 10.1093/petrology/egy097.

Stagno, V., \& Frost, D.J. (2010). C.rbon speciation in the asthenosphere: Experimental measurements of the redox $u$ nd $:$ ins at which carbonate-bearing melts coexist with graphite or diamond in peridotite ass $\mathrm{m}^{2}$, ages. Earth and Planetary Science Letters, 300 , 72-84, doi: 10.1016/j.epsl.2010.09.038.

Stagno, V., Ojwang, D.O., Mc.mmon, C.A., \& Frost, D.J. (2013). The oxidation state of the mantle and the extraction of carbon from Earth's interior. Nature, 493, 84-88, doi: 10.1038/nature11679.

Stamm, N., \& Schmic M.W. (2017). Asthenospheric kimberlites: Volatile contents and bulk compositions at 7 (??. Earth and Planetary Science Letters, 474, 309-321, doi: 10.1016/j.epsl.2017.06.037

Suetsugu, D., Thi har, H., Sugioka, H., Ito, A., Isse, T., Kasaya, T., Tada, N., Baba, K., Abe, N., Hamano, Y., Tarits, P., Barriot, J.-P., \& Reymond, D. (2012). TIARES ProjectTomographic investigativis by seafloor array experiment for the Society hotspot. Earth, Planets and Space, 64, 4 pp., doi: 10.5047/eps.2011.11.002.

Sun, C., Dasgupta, R. (2019). Slab-mantle interaction, carbon transport, and kimberlite generation in the deep upper mantle. Earth and Planetary Science Letters, 506, 3852, doi: 10.1016/j.epsl.2018.10.028.

Tada, N., Tarits, P., Baba, K., Utada, H., Kasaya, T., \& Suetsugu, D. (2016). Electromagnetic evidence for volatile-rich upwelling beneath the society hotspot, French Polynesia. Geophysical Research Letters, 43, 12021-12026, doi: 10.1002/2016GL071331.

Tappe, S., Foley, S.F., Stracke, A., Romer, R.L., Kjarsgaard, B.A., Heaman, L.M., \& Joyce, N. (2007). Craton reactivation on the Labrador Sea margins: ${ }^{40} \mathrm{Ar} /{ }^{39} \mathrm{Ar}$ age and $\mathrm{Sr}-\mathrm{Nd}-$ $\mathrm{Hf}-\mathrm{Pb}$ isotope constraints from alkaline and carbonatite intrusives. Earth and Planetary Science Letters, 256, 433-454, doi: 10.1016/j.epsl.2007.01.036. 
Tappe, S., Pearson, D.G., Kjarsgaard, B.A., Nowell, G., \& Dowall, D. (2013). Mantle transition zone input to kimberlite magmatism near a subduction zone: Origin of anomalous $\mathrm{Nd}-\mathrm{Hf}$ isotope systematics at Lac de Gras, Canada. Earth and Planetary Science Letters, 371 372, 235-251, doi: 10.1016/j.epsl.2013.03.039.

Tappe, S., Smart, K.A., Stracke, A., Romer, R.L., Prelević, D, \& van den Bogaard, P. (2016). Melt evolution beneath a rifted craton edge: 40Ar/39Ar geochronology and $\mathrm{Sr}-\mathrm{Nd}-$ $\mathrm{Hf}-\mathrm{Pb}$ isotope systematics of primitive alkaline basalts and lamprophyres from the SW Baltic Shield. Geochimica et Cosmochimica Acta, 173, 1-36, doi: 10.1016/j.gca.2015.10.006.

Tappe, S., Romer, R.L., Stracke, A., Steenfelt, A., Smart, K.A., Muehlenbachs, K., \& Torsvik, T.H. (2017). Sources and mobility of carbonate melts beneath cratons, with implications for deep carbon cycling, metasomatism and riftinitiation. Earth and Planetary Science Letters, 466, 152-167, doi: 10.1016/j.epsl.2017.03.011.

Tappe, S., Smart, K., Torsvik, T., Massuyeau, M., \& de Wit, M. (2018). Geodynamics of kimberlites on a cooling Earth: Clues to plate tectonic ev in and deep volatile cycles. Earth and Planetary Science Letters, 484, 1-14, doi: 10.1016/, eps ..2017.12.013.

Tappe, S., Budde, G., Stracke, A., Wilson, A., \& Klei ıe, T. (2020). The tungsten-182 record of kimberlites above the African superplume: Exploring links to the core-mantle boundary. Earth and Planetary Science Letters, 547, 4 r )., doi: 10.1016/j.eps1.2020.116473.

Tharimena, S., Rychert, C., Harmon, N., \& White, P. (2017a). Imaging Pacific lithosphere seismic discontinuities-Insights fr $\mathrm{s}$. SS precursor modeling. Journal of Geophysical Research: Solid Earth, 122, 2131 2: 5?, doi: 10.1002/2016JB013526.

Tharimena, S., Rychert, C., \& 'iarı ın, N. (2017b). A unified continental thickness from seismology and diamonds suggests . melt-defined plate. Science, 357, 580-583, doi: 10.1126/science.aan0741.

Tumiati, S., Fumagalli, P., Trra i scchi, C., \& Poli, S. (2013). An Experimental Study on $\mathrm{COH}$-bearing Peridotite up th $2 . \mathrm{GPa}$ and Implications for Crust-Mantle Recycling. Journal of Petrology, 54, 453-47' ' do: 10.1093/petrology/egs074.

van Keken, P.E., Ha'kt: B.R., Syracuse, E.M., \& Abers, G.A. (2011). Subduction factory: 4. Depth-dependent $\mathrm{th} \times$ of $\mathrm{H}_{2} \mathrm{O}$ from subducting slabs worldwide. Journal of Geophysical Research, 1 v, 1 j pp., doi: 10.1029/2010JB007922.

Wallace, M.E., 女 ureen, D.H. (1988). An experimental determination of primary carbonatite magma comoo ition. Nature, 335, 343-346, doi:10.1038/335343a0.

Wang, D., Mookherjee, M., Xu, Y., \& Karato, S.-I. (2006). The effect of water on the electrical conductivity of olivine. Nature, 443, 977-980, doi: 10.1038/nature05256.

Weidendorfer, D., Schmidt, M.W., \& Mattsson, H.B. (2017). A common origin of carbonatite magmas. Geology, 45, 4 pp., doi: 10.1130/G38801.1.

Weiss, Y., Griffin, W.L., Bell, D.R., \& Navon, O. (2011). High-Mg carbonatitic melts in diamonds, kimberlites and the sub-continental lithosphere. Earth and Planetary Science Letters, 309, 337-347, doi: 10.1016/j.epsl.2011.07.012.

Yaxley, G.M., Berry, A.J., Rosenthal, A., Woodland, A.B., \& Paterson, D. (2017). Redox preconditioning deep cratonic lithosphere for kimberlite genesis - evidence from the central Slave Craton. Scientific Reports, 7, 10 pp., doi: 10.1038/s41598-017-00049-3. 
Zhang, G.-L., Chen, L.-H., Jackson, M. G., \& Hofmann, A.W. (2017). Evolution of carbonated melt to alkali basalt in the South China Sea. Nature Geoscience, 10, 229-235, doi: 10.1038/NGEO2877. 


\section{Figures}

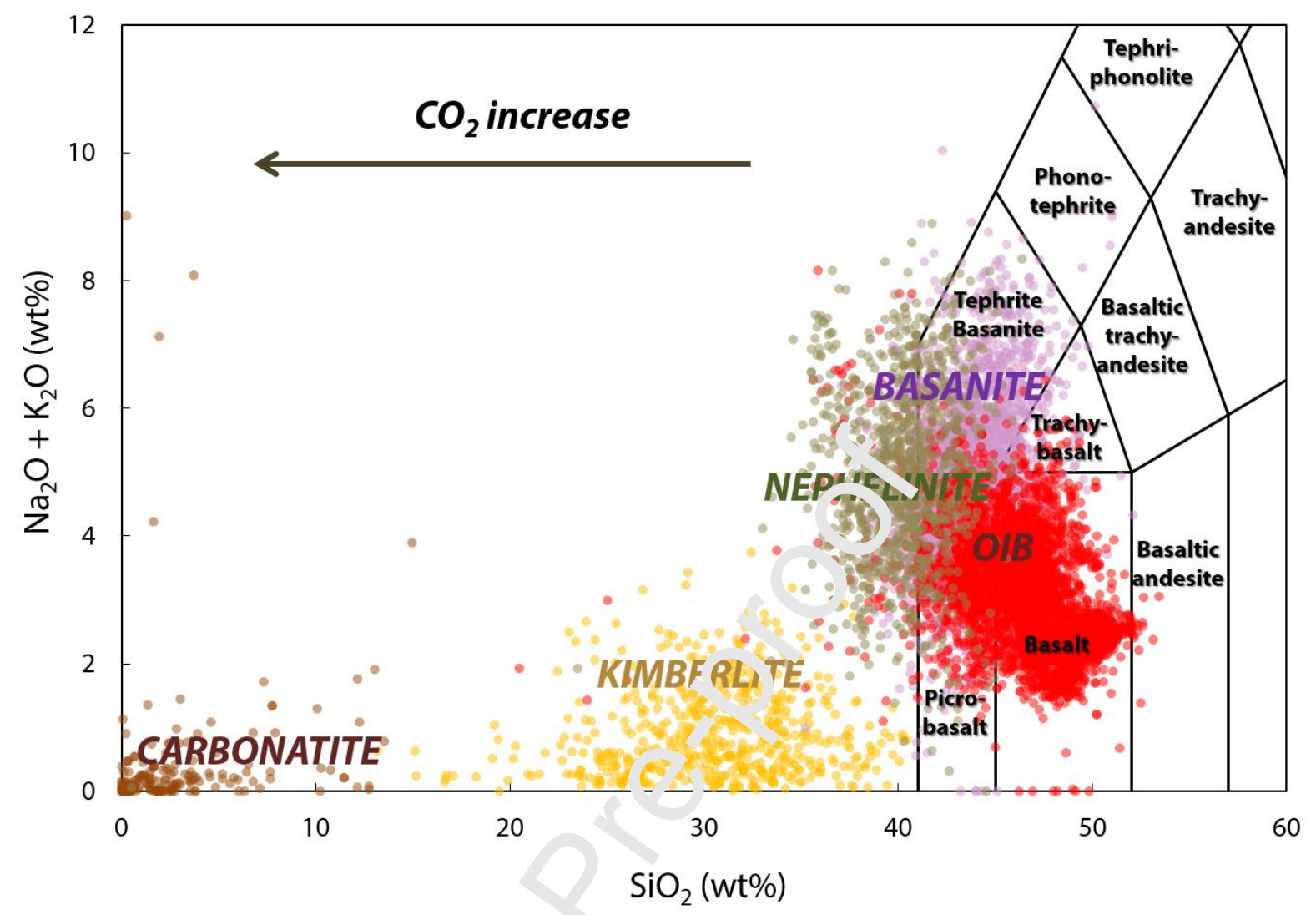

Fig. 1. Compositional rang ji natural intraplate melts, from low- $\mathrm{SiO}_{2}$ carbonatitic melts to basaltic melts. Carbonatit $\_$( «.own dots), nephelinites (green dots), basanites (purple dots) and OIBs (red dots) are olected from the GEOROC database (http://georoc.mpchmainz.gwdg.de). Kimberlites ( $y$-llow dots) are from the compilation of Tappe et al. (2017; see their Supplementary File $\square$ and references therein). Lava compositions were selected from GEOROC database has: on $\mathrm{MgO}$ content: carbonatites have $\mathrm{MgO}$ contents $>12 \mathrm{wt} \%$ (and $\mathrm{SiO}_{2}$ contents $<15 \%$ to remove anomalous outliers), while nephelinites, basanites and OIBs have $\mathrm{MgO}$ contents $>8 \mathrm{wt} \%$ and $<16 \mathrm{wt} \%$. 


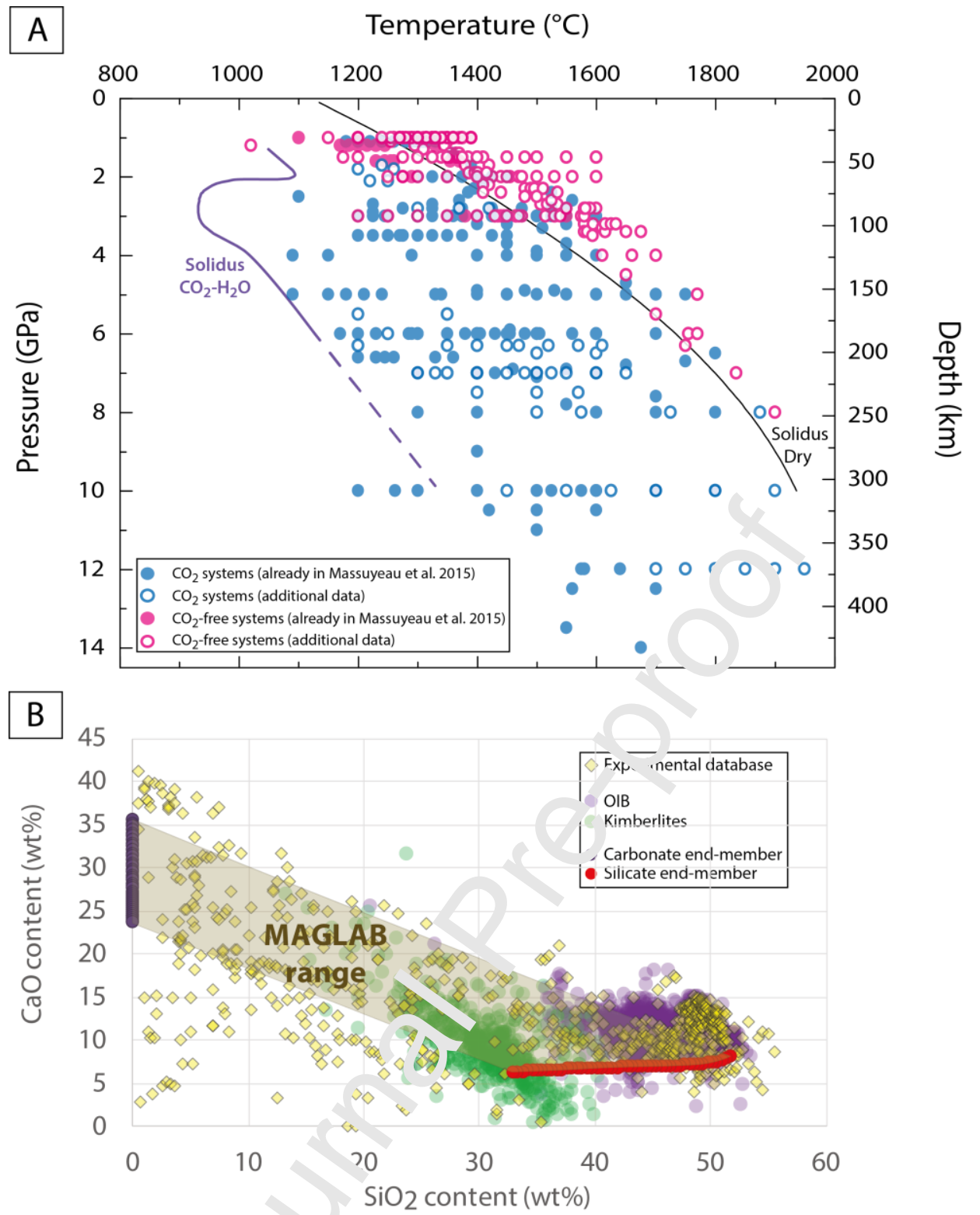

Fig. 2. Experin enta database of melt compositions used for the calibration of MAGLAB. The desci in of the experimental database (i.e., pressure, temperature and composition space of mel's) is presented in Table S3. All melts coexist with a typical mantle assemblage (i.e., saturated in olivine-opx \pm cpx \pm garnet/spinel). (A) Pressure/depth-temperature space. The data range from 1 to $14 \mathrm{GPa}$ and from 1020 to $1950^{\circ} \mathrm{C}$. Melting curves for different bulk peridotite conditions are also reported as a function of temperature and pressure/depth conditions (dry solidus from Hirschmann (2000); $\mathrm{CO}_{2-}$ and $\mathrm{H}_{2} \mathrm{O}$-bearing solidus from Wallace and Green (1988) from $\sim 1$ to $\sim 4 \mathrm{GPa}$, and Foley et al. (2009) between 4 and $6 \mathrm{GPa}$, with extrapolation up to $10 \mathrm{GPa}$ as shown by the dashed purple curve). (B) $\mathrm{CaO}$ $\mathrm{SiO}_{2}$ compositional space (see Fig. S3 for other major elements). The compositions of the silicate and carbonate melt end-members of our model are shown as red and purple circles, respectively. Combining these end-members yields compositions (light maroon shaded areas) covering a large proportion of the experimental database (yellow diamonds) as well as the chemical diversity of intraplate magmatism, from kimberlites to OIBs (green and light purple circles, respectively; see Fig. 1). 


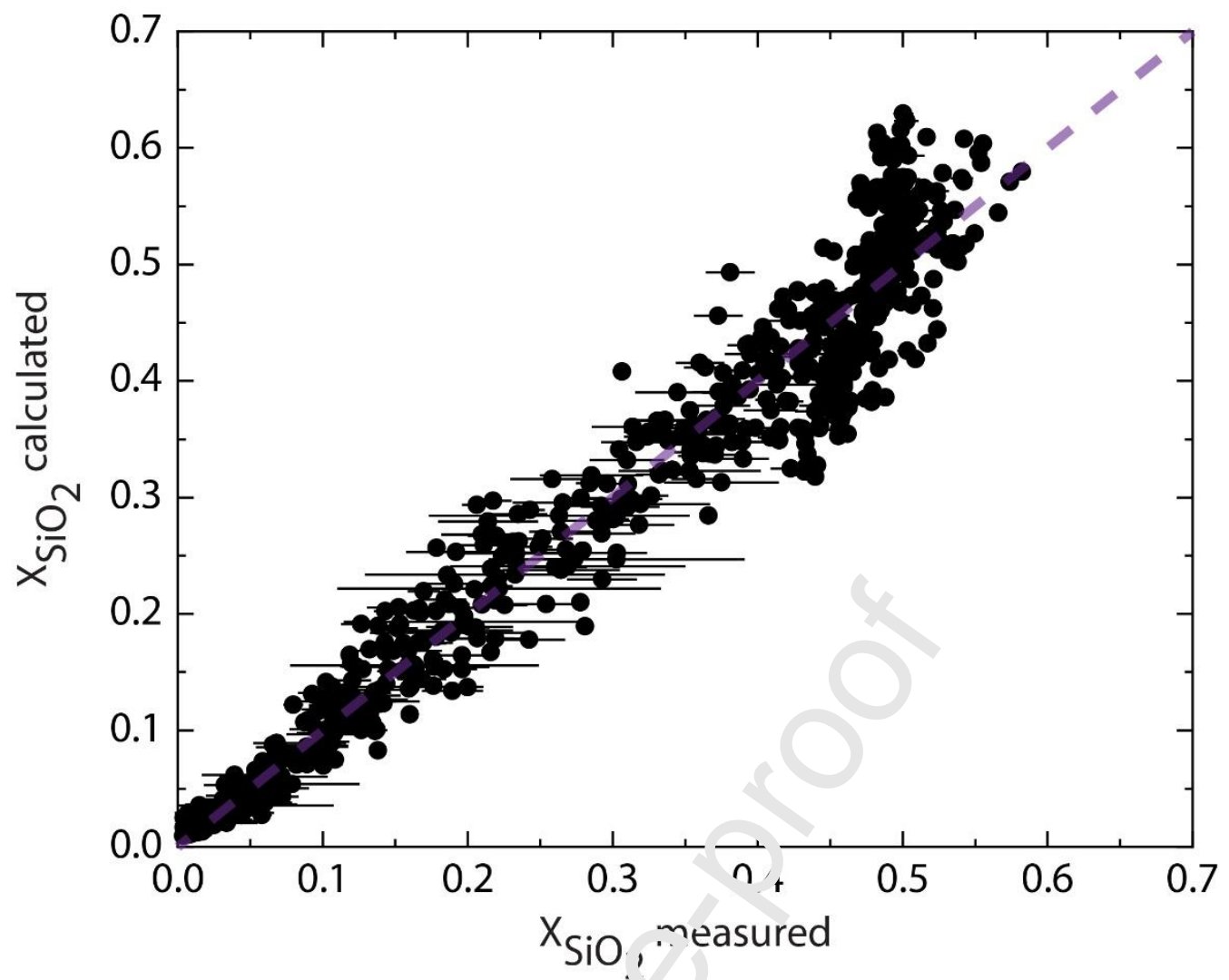

Fig. 3. Comparison of the molar $f_{u}{ }^{+}{ }^{i} o_{1}$ of $\mathrm{SiO}_{2}$ in melt calculated with MAGLAB to

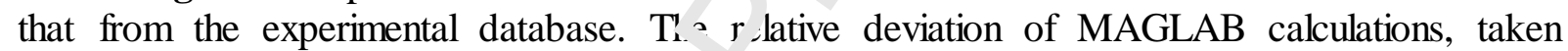

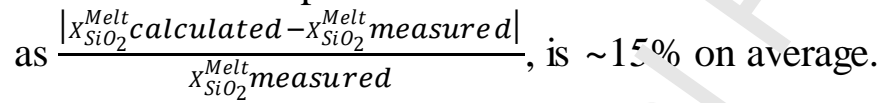



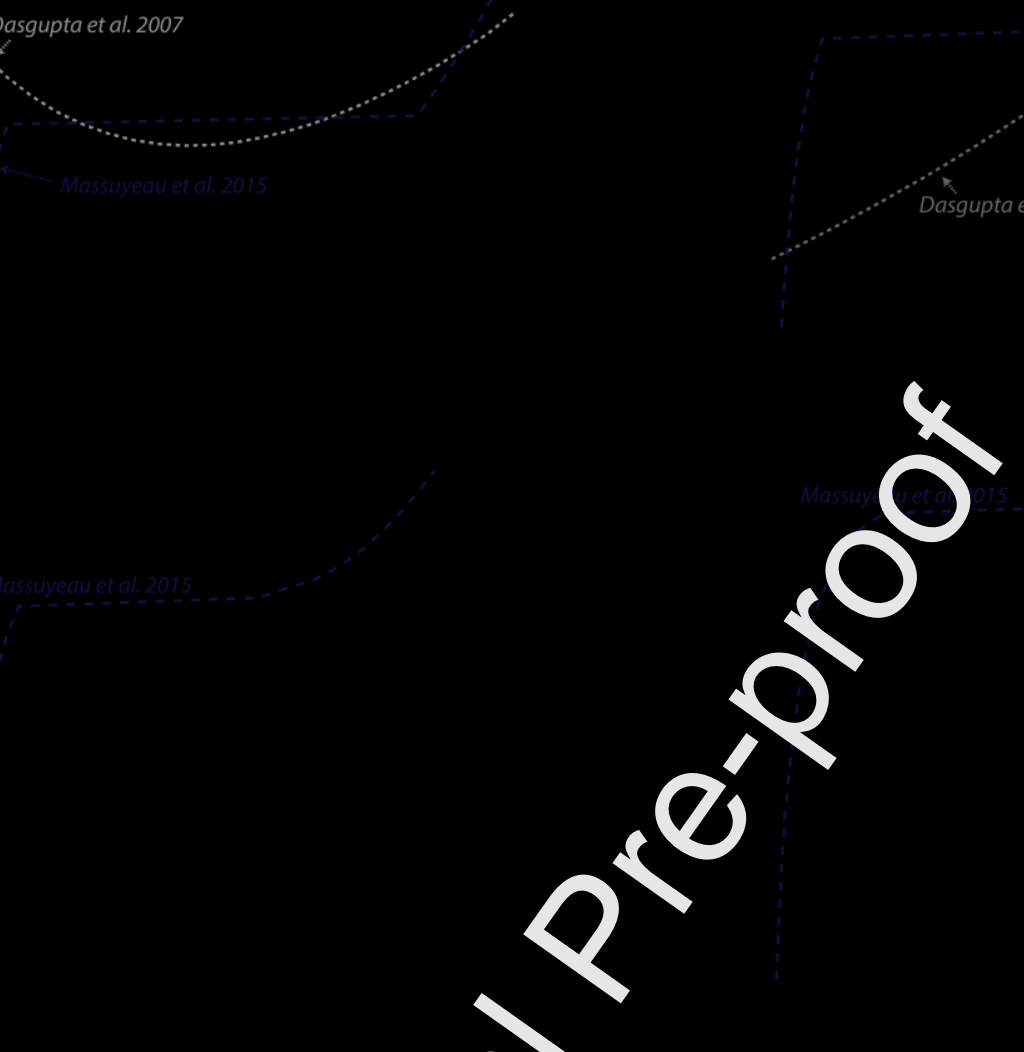

Fig. 4: Comparison of melt $\mathrm{Si} / 2$ content calculated by MAGLAB with experimental data at (A) $3 \mathrm{GPa}$, (B) $5 \mathrm{GPa}$, (C.) : GPa, and (D) $10 \mathrm{GPa}$. Also compared are the models of Dasgupta et al. (2007), Dasgu.ta st al. (2013) and Massuyeau et al. (2015) in their pressure range of applicability (3 GPa, $5 \mathrm{C}$ a, and from $\sim 2$ to $10 \mathrm{GPa}$, respectively) at a bulk rock $\mathrm{CO}_{2}$ content of $140 \mathrm{wt}$ ppm (i.e., ave dge mantle source; Le Voyer et al., 2017). Experimental melts reported here are $\mathrm{H}_{2} \mathrm{O}$-fr $\mathrm{e}$, ontain at least $\mathrm{SiO}_{2}, \mathrm{Al}_{2} \mathrm{O}_{3}, \mathrm{MgO}, \mathrm{CaO}, \mathrm{FeO}$ and $\mathrm{CO}_{2}$, and match pressure within $\pm 0.5 \mathrm{C}^{\mathrm{D}} \mathrm{a}$. 


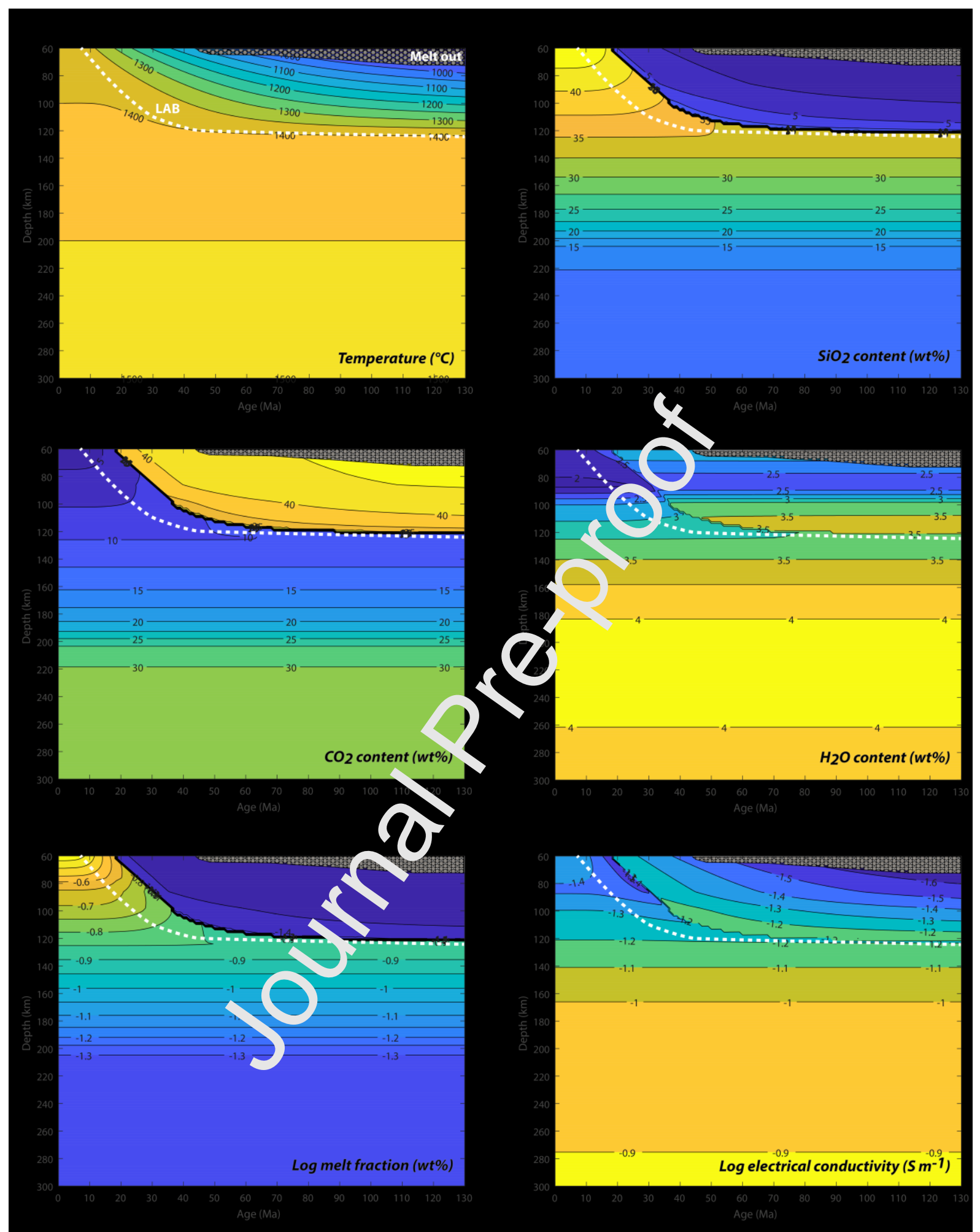

Fig. 5: Contours of MAGLAB equilibrium melt composition, melt fraction and electrical conductivity for oceanic upper mantle with average volatile content (140 wt ppm $\mathrm{CO}_{2}-240$ wt ppm $\mathrm{H}_{2} \mathrm{O}$; Le Voyer et al., 2017) as a function of depth and age. (A) Mantle thermal structure with potential temperature $T_{P}=1350^{\circ} \mathrm{C}$ from Grose and Afonso (2013) (G13R1350 model). (B) $\mathrm{SiO}_{2}$, (C) $\mathrm{CO}_{2}$, and (D) $\mathrm{H}_{2} \mathrm{O}$ contents of melts. (E) Melt fraction. (F) Bulk mantle electrical conductivity. The dotted grey areas (i.e., 'Melt out') at the top of each panel correspond to the subsolidus region (Wallace and Green, 1988). The dashed white curve is an estimation of the LAB depth. 
A

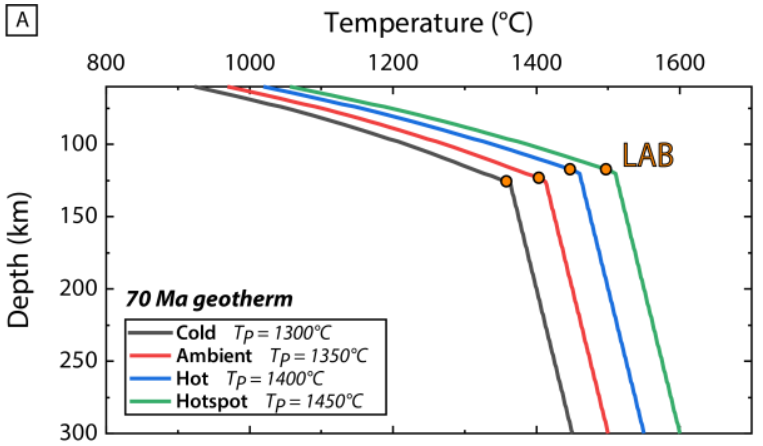

C
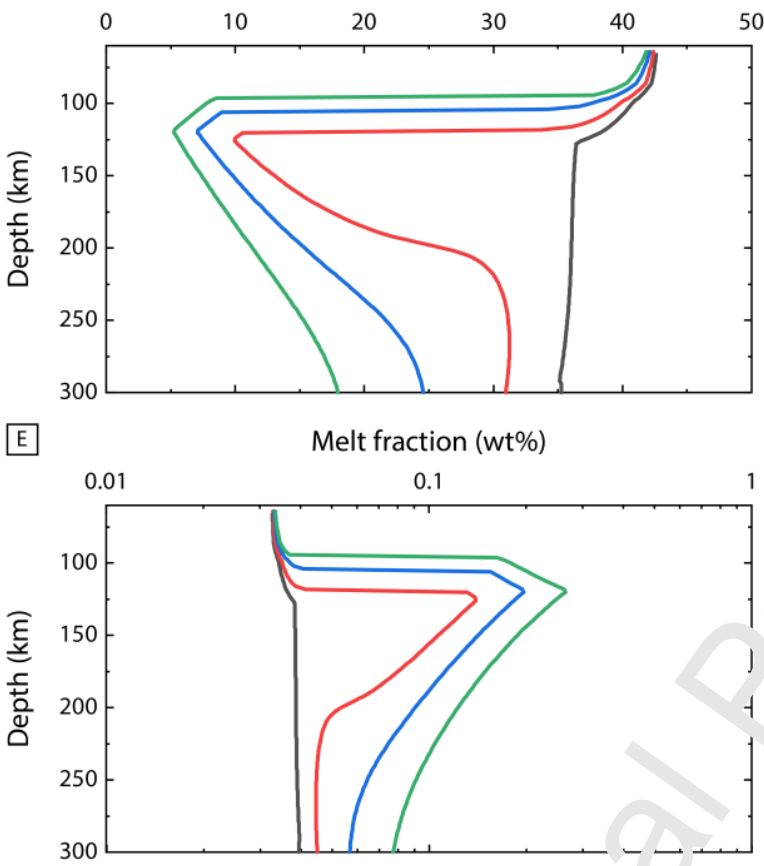

$\mathrm{B}$

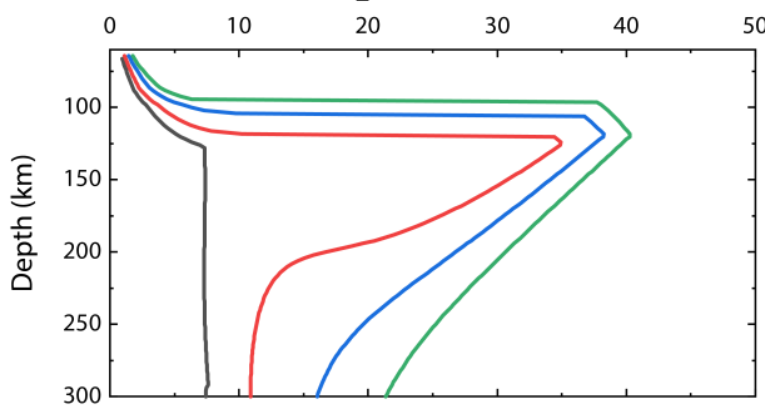

$D$
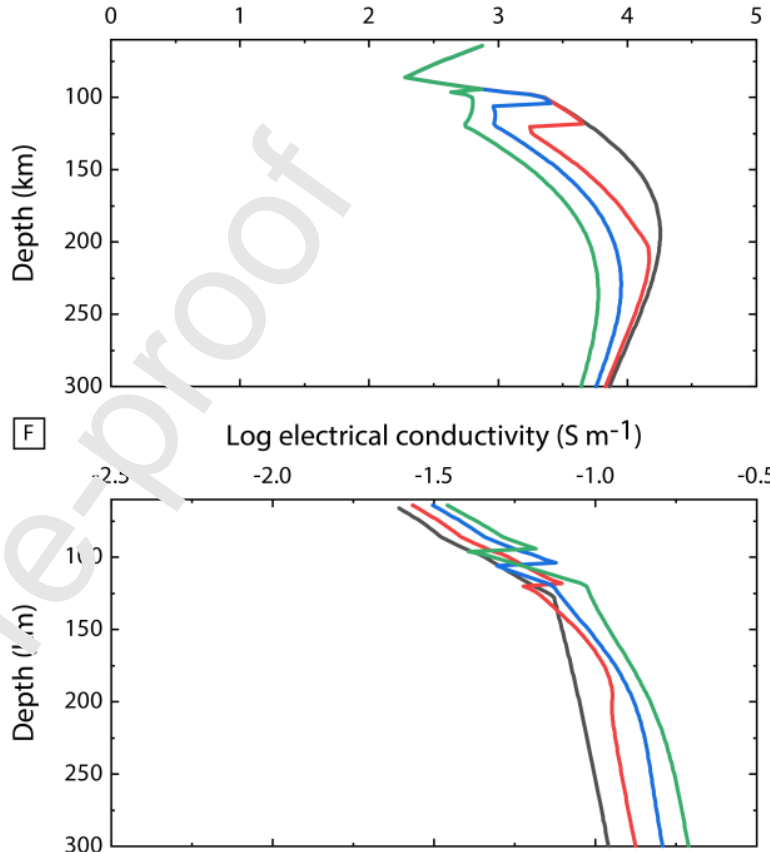

Fig. 6: MAGLAB es, uilibium melt composition, melt fraction and electrical conductivity for oceanic upper nantie at $70 \mathrm{Ma}$ as a function of depth and $T_{P}$, with average volatile content (140 wt ppm $\mathrm{CO}_{2}-240$ wt ppm $\mathrm{H}_{2} \mathrm{O}$; Le Voyer et al., 2017). (A) Mantle thermal structures with poteni. 1 emperature $T_{P}=1300,1350,1400$ and $1450^{\circ} \mathrm{C}$ from Grose and Afonso (2013) (G12R13)0, G13R1350, G13R1400, and G13R1450 models, respectively). (B) $\mathrm{SiO}_{2}$, (C) $\mathrm{CO}_{2}, a^{\prime}$ (D) $\mathrm{H}_{2} \mathrm{O}$ contents of melts. (E) Melt fraction. (F) Bulk mantle electrical conductivity. Tr: orange circles in panel (A) provide an estimation of the LAB depth. 

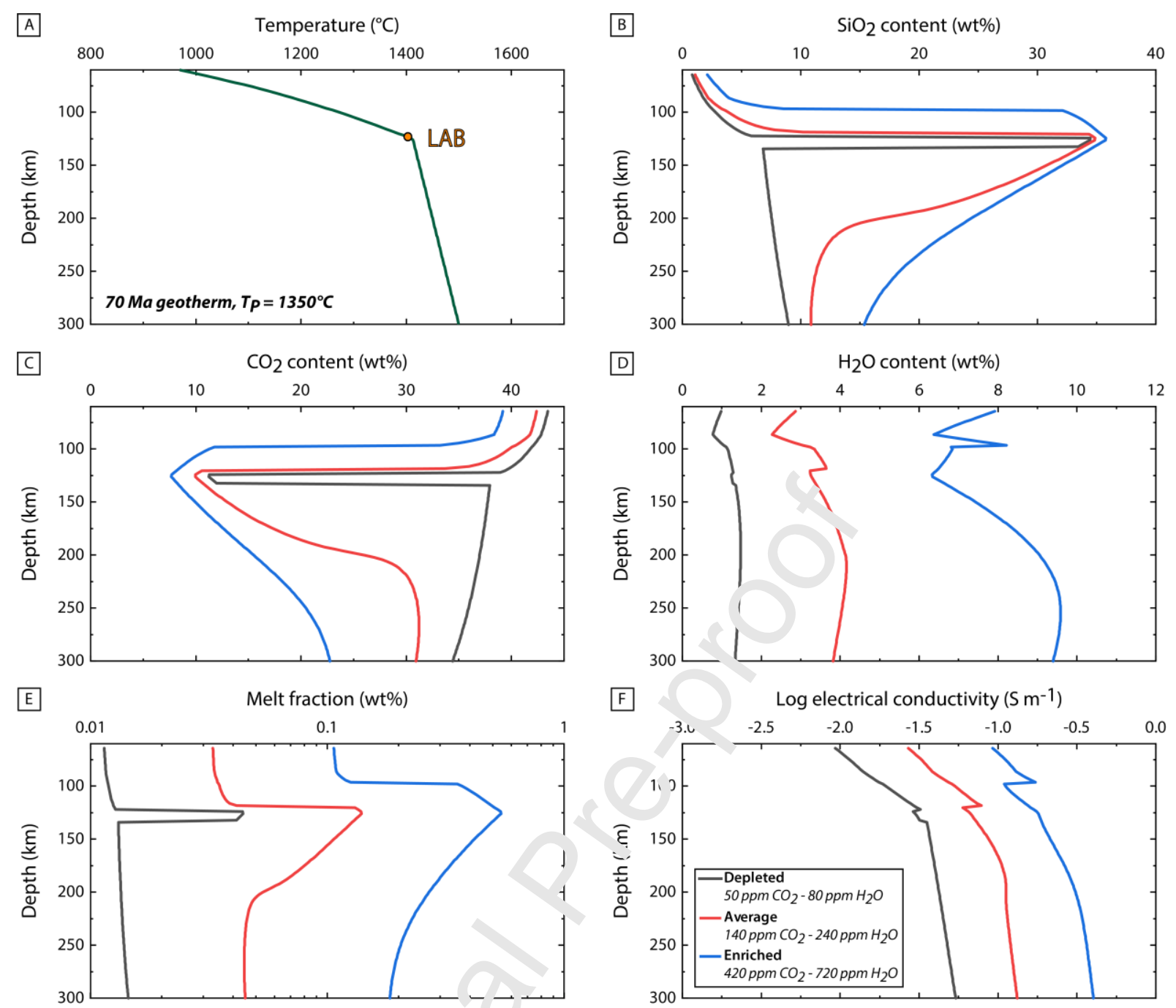

Fig. 7: MAGLAB enuilit um melt composition, melt fraction and electrical conductivity for oceanic upper ma. ${ }^{+1}$ at $70 \mathrm{Ma}$ with various volatile contents $(50 \mathrm{wt} \mathrm{ppm}$ $\mathrm{CO}_{2}-80$ wt ppm $\mathrm{H}_{2} \mathrm{O}, 140$, ${ }^{\dagger} \mathrm{prm} \mathrm{CO}_{2}-240$ wt ppm $\mathrm{H}_{2} \mathrm{O}$, and 420 wt ppm $\mathrm{CO}_{2}-720$ wt ppm $\mathrm{H}_{2} \mathrm{O}$ ) as a function oi ter th. (A) Mantle thermal structure with potential temperature $T_{P}$ $=1350^{\circ} \mathrm{C}$ from Grose c nd .1fonso (2013) (G13R1350 model). (B) $\mathrm{SiO}_{2}$, (C) $\mathrm{CO}_{2}$, and (D) $\mathrm{H}_{2} \mathrm{O}$ contents of melts. $(\mathrm{L}$ ), Melt fraction. (F) Bulk mantle electrical conductivity. The orange circle in panel (A) provide an estimation of the LAB depth. 

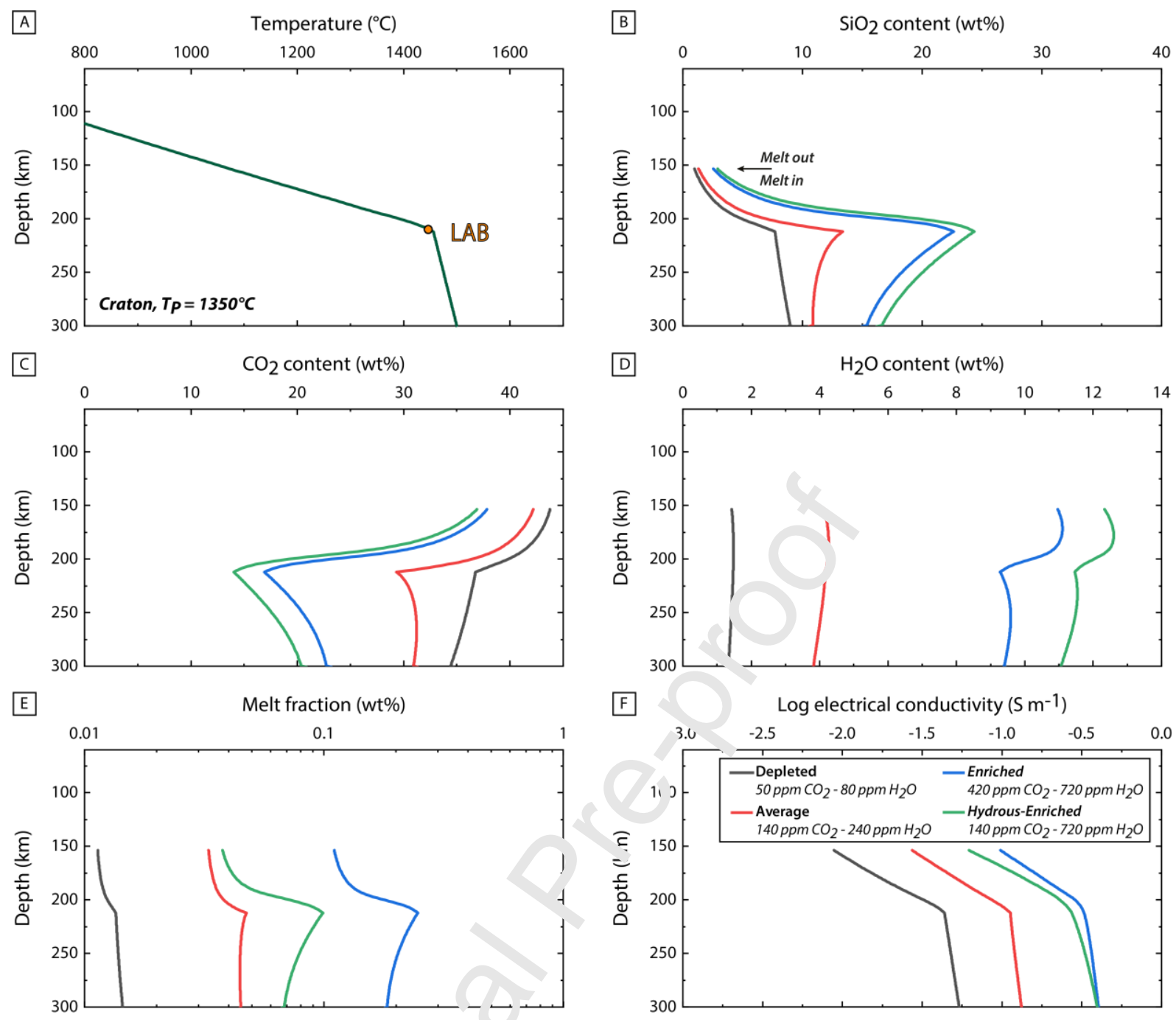

Fig. 8: MAGLAB ey ilibrium melt composition, melt fraction and electrical conductivity for cratonic upper, antle with various volatile contents $\left(50 \mathrm{wt} \mathrm{ppm} \mathrm{CO}_{2}-80 \mathrm{wt}\right.$ ppm $\mathrm{H}_{2} \mathrm{O}, 140$ wt ppm $\mathrm{CO}_{2}-210$ wt ppm $\mathrm{H}_{2} \mathrm{O}, 420$ wt ppm $\mathrm{CO}_{2}-720$ wt ppm $\mathrm{H}_{2} \mathrm{O}$, and 140 wt ppm $\mathrm{CO}_{2}-720$ wt $n_{n} \mathrm{~h}_{1} \mathrm{I}_{i_{2}} \mathrm{O}$ ) as a function of depth. (A) Mantle thermal structure with potential temperature $T_{P}=1350^{\circ} \mathrm{C}$ calculated with the numerical FITPLOT model (McKenzie and Bickle, 1988; Man.'r et al., 2011) by fitting xenolith P-T array from a typical cratonic mantle (here, we conside the North Atlantic Craton beneath southern West Greenland; see more details in Fig. S6 and its caption). (B) $\mathrm{SiO}_{2}$, (C) $\mathrm{CO}_{2}$, and (D) $\mathrm{H}_{2} \mathrm{O}$ contents of melts. (E) Melt fraction. (F) Bulk mantle electrical conductivity. The orange circle in panel (A) provides an estimation of the LAB depth. "Melt in" vs "Melt out" labels denote the depth at which mantle geotherm crosses the $\mathrm{CO}_{2}-\mathrm{H}_{2} \mathrm{O}$-bearing peridotite solidus, and consequently delimits the top of the mantle melting zone; while the electrical conductivity calculations are performed by MAGLAB only for partially molten peridotite rocks, solid state mechanisms govern the mantle electrical conductivity in its shallow subsolidus portions. 


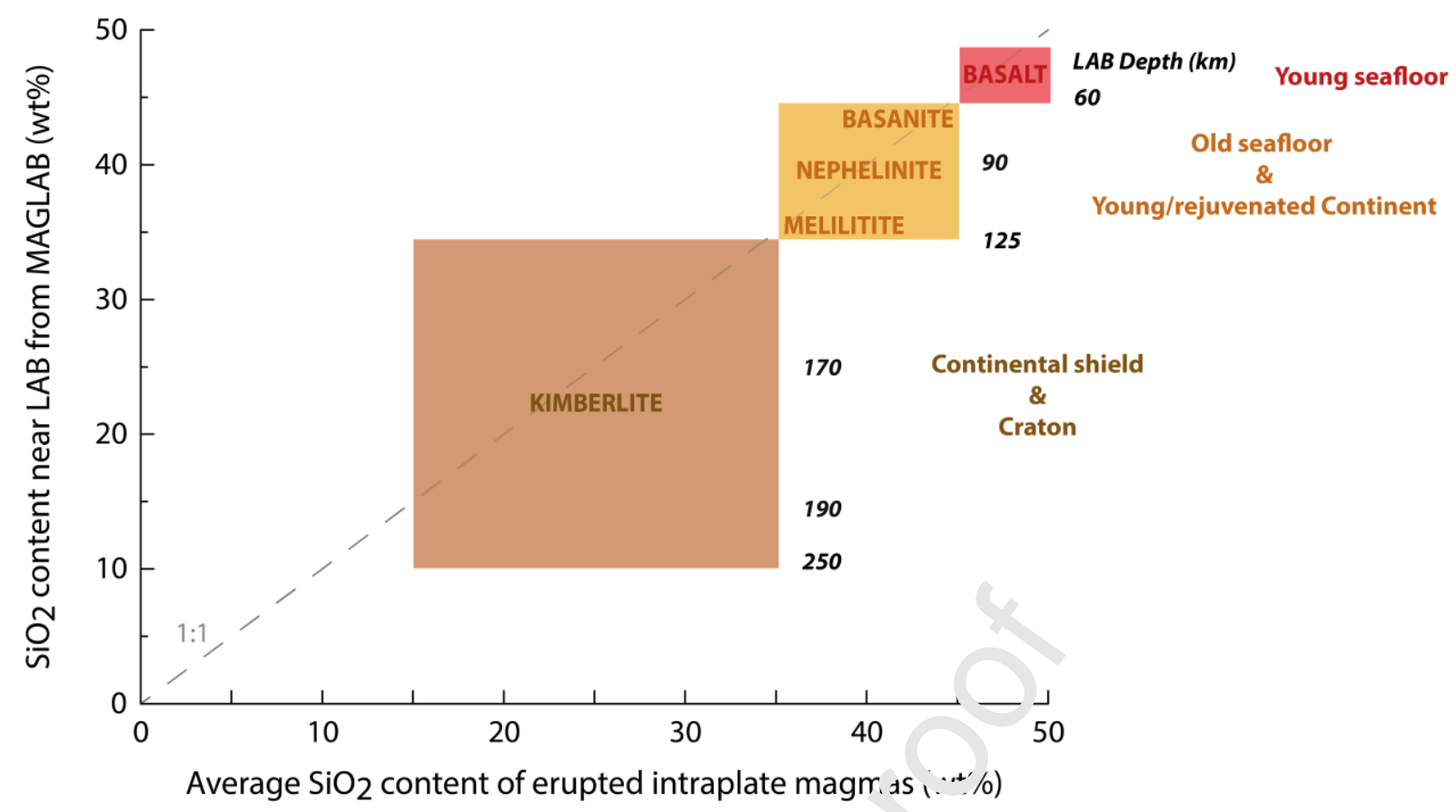

Fig. 9: Correspondence of the composition of intraplate magmas observed at the Earth's surface with the composition of primitive melts cquilibrated at LAB depth calculated with MAGLAB. Different tectonic settings are $\operatorname{cs}$ ridered: (i) Young seafloor (i.e., modern oceanic plate with age $<10 \mathrm{Ma}$ ) with a LAP de $\mu \mathrm{n}<\sim 60 \mathrm{~km}$; (ii) Old seafloor (i.e., modern oceanic plate with age $>10 \mathrm{Ma}$ ) and Yo'.ng/ ejur znated Continent, with a LAB depth between 60 and $125 \mathrm{~km}$; (iii) Continental shield an' Craton, with a LAB depth between 125 and 250 $\mathrm{km}$. MAGLAB calculations are perf. med by varying the depth of the LAB as a function of the tectonic setting (see $P-T$ conditin $n$ in Fig. S7), and considering a single average mantle source with 140 wt ppm $\mathrm{CO}_{2}-24 \mathrm{C}$ v c l, $\mathrm{pm} \mathrm{H}_{2} \mathrm{O}$ (Le Voyer et al., 2017). Similarly to the TAS diagram (e.g. Fig. 1), the melt $\boldsymbol{~}$ ( content is here used as a proxy for the compositional range of intraplate magmas as $\mathrm{k}$ 'nd at the Earth's surface: 15-35 wt\% for kimberlites, a progressive transition between 5 to $45 \mathrm{wt} \%$ from melilitite to nephelinite to basanite, and $>45 \mathrm{wt} \%$ for regular basak $\mathrm{N}$ te OIB compositions as reported in Fig. 1 span basanitic to basaltic compositions. 


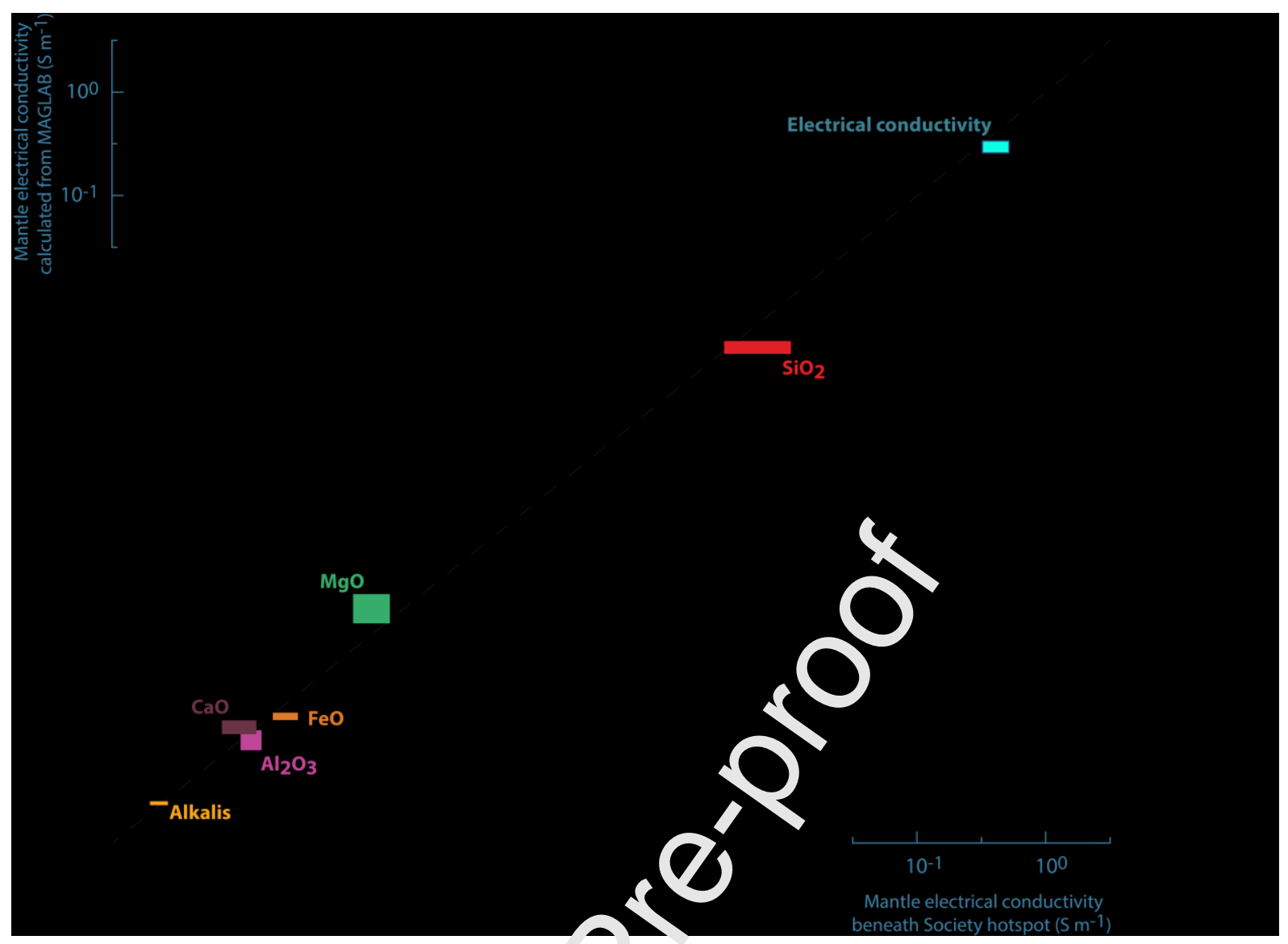

Fig. 10: Reproducing the petrolos $\therefore \lambda$ and electrical data at the LAB beneath Society hotspot (Pacific Ocean) using MAGL AB. Caiculations are performed at LAB depth $(120 \pm 10$ $\mathrm{km})$ according to the $P-T$ conditions anc mantle volatile content reported for the hotspot. The reported mantle potential temperatu $=1$ is $1450^{\circ} \mathrm{C}$ (Herzberg and Asimow, 2008; mantle thermal structure simulated with ' Ji2ki450 model from Grose and Afonso 2013), and the mantle volatile content is $\sim 700 \mathrm{r} \cdot \mathrm{t}, \mathrm{nm} \mathrm{CO} \mathrm{CO}_{2}$ and $720 \mathrm{wt} \mathrm{ppm}_{2} \mathrm{O}$ (Aubaud et al., 2005). The average major element comrosi ins of near-primary OIBs reported for the Society Islands are from Dasgupta et al. (?Ol6 , on a volatile-free basis (also applied to the melt compositions from MAGLAB simulat:- $\backsim$. The high mantle electrical conductivities reported beneath Society hotspot are sth ate 1 within 110-130 km depth from the averaged 1-D electrical conductivities (Tada et ai. (2016); see also Fig. 11: "Anomaly Zone A, Society Islands"). 


\section{Log electrical conductivity (S m-1)}

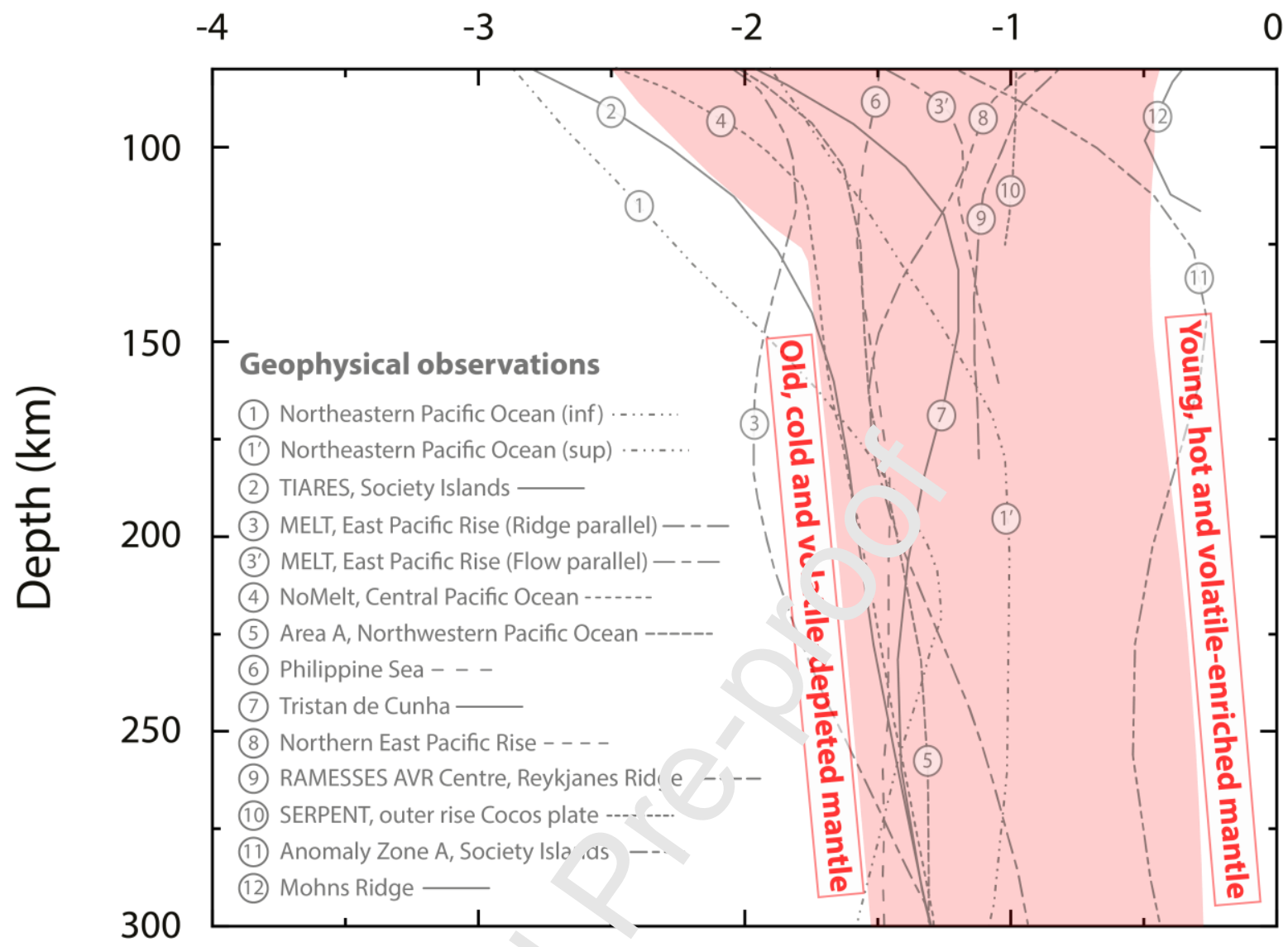

Fig. 11: Comparison betwe 1 . lecrical profiles observed beneath various ocean floors and MAGLAB simulations. MACLL $\mathrm{R}$ conductivities for partially molten peridotite rocks (light red area) range from (i) sld, cold and highly depleted mantle (130 Ma, with $T_{P}=$ $1300^{\circ} \mathrm{C}$ and 20 wt ppm $\mathrm{CO}_{2} \cdot 50$ wt ppm $\mathrm{H}_{2} \mathrm{O}$ ) to (ii) young, hot and highly enriched mantle (0 Ma, with $T_{P}=1450^{\circ} \mathrm{C}$ aı ${ }^{4} / 00$ wt ppm $\mathrm{CO}_{2}-720$ wt ppm $\mathrm{H}_{2} \mathrm{O}$ ). The mantle thermal structures are G13R1300 an' C13R1450 models from Grose and Afonso (2013), with $T_{P}=$ $1300^{\circ} \mathrm{C}$ and $1450^{\circ} \mathrm{C}$ re spec ively. Electrical conductivity profiles of the oceanic upper mantle in dark grey are fron. vaı ious magnetotelluric studies. 1 and 1', conductivity profile in the northeastern Pacific Ore: $n$ between Hawaii and California (Lizarralde et al., 1995). 2, Tomographic Investigation by seafloor ARray Experiment for the Society hotspot (TIARES) profile representing the 'background' mantle beneath the Society hotspot in the Pacific Ocean (Tada et al., 2016). 3 and 3', Mantle Electromagnetic and Tomography (MELT) profile in the region of the East Pacific Rise (Evans et al., 2005; Baba et al., 2006). 4, conductivity profile in the central Pacific Ocean ("NoMelt" experiment in Sarafian et al., 2015). 5, conductivity profile in the northwestern Pacific Ocean ("Area A" in Baba et al., 2013, 2017b). 6, conductivity profile beneath the Philippine Sea (Baba et al., 2010). 7, conductivity profile beneath the Tristan da Cunha hotspot in the southern Atlantic Ocean (Baba et al., 2017a). 8, conductivity profile in the northern East Pacific Rise (Key et al., 2013). 9, Reykjanes Axial Melt Experiment: Structural Synthesis from Electromagnetics and Seismics (RAMESSES) profile in the northern section of the Mid-Atlantic Ridge, i.e. the Reykjanes Ridge ("AVR Centre" in Heinson et al., 2000). 10, Serpentinite, Extension, and Regional Porosity Experiment across the Nicaragua Trench (SERPENT) profile beneath the outer rise of 22-24 Ma Cocos plate seafloor in the Pacific Ocean (Naif et al., 2013; Naif, 2018). 11, conductivity 
profile of a high-conductivity anomaly reported beneath the Society hotspot in the Pacific Ocean ("Zone A" in Tada et al., 2016). 12, conductivity profile beneath the Mohns Ridge ("3 Myr W" profile in Johansen et al., 2019). 
No CRediT author statement. If this is mandatory, we will be pleased to provide it. 
$x$ This image

cannot

currently be
displayed. 


\section{Highlights}

- Combined petrology-geophysics inputs to model melting processes in the upper mantle

- Intraplate magma compositions relate to lithosphere thickness

- Quantification of melt fractions and $\mathrm{CO}_{2}-\mathrm{H}_{2} \mathrm{O}$ contents down to $300 \mathrm{~km}$ depth

- Heterogeneous mantle conductivities related to variable volatile contents 